\title{
Current Policy
} Perspectives

\section{Wage Inflation and Informal Work}

\author{
Anat Bracha and Mary A. Burke
}

\begin{abstract}
:
Despite very low unemployment in the United States in recent months, wage inflation has remained modest. This paper investigates the possibility that there is hidden labor market slack in the form of informal or gig economy work, which may help explain this wage growth puzzle. Using unique data from 2015 and 2016 that we collected through the Survey of Informal Work Participation - part of the Federal Reserve Bank of New York's Survey of Consumer Expectations-we find indirect and direct evidence for this hypothesis. First, we find that a measure of informal labor is negatively associated with wage growth at the census division level, while we observe no significant association between wage growth and the U-3 or U-6 unemployment rate. Second, most informal work participants in our survey report that for some increase in pay, they would drop hours of informal work in exchange for added hours of formal work. Together our results suggest that informal work represents an economically significant amount of potential labor supply to the formal market that may reduce pressure on measured wages. We also discuss other interpretations of our data.
\end{abstract}

JEL Classification: J46, J21, E24, E26

Keywords: wage inflation, gig economy, labor market slack

Anat Bracha is a senior economist in the research department of the Federal Reserve Bank of Boston. Her e-mail address is anat.bracha@bos.frb.org. Mary Burke is a senior economist in the research department of the Federal Reserve Bank of Boston. Her e-mail address is mary.burke@bos.frb.org.

This paper, which may be revised, is available on the website of the Federal Reserve Bank of Boston at http://www.bostonfed.org/economic/current-policy-perspectives/index.htm.

The views expressed in this paper are those of the authors and do not necessarily represent the views of the Federal Reserve Bank of Boston or the Federal Reserve System.

We would like to thank Giovanni Olivei, Joe Peek, Geoff Tootell, and Chris Foote for helpful comments and discussions, and Jimin Nam for excellent research assistance.

This version: October 2017 
In spite of the low unemployment rate in the United States since February 2017-below the estimated natural rate-wage inflation has remained modest. According to Adam Ozimek of Moody's, recent year-over-year wage growth values (based on the Employment Cost Index, or ECI) fall short of their predicted values by 0.5 to 1 percentage point (see Figure 1 and Ozimek 2017). Recent acceleration in wage growth relative to declines in unemployment also falls short of historical norms. (Examining these latter outcomes controls for changes in long-run trend wage growth and changes in the natural rate of unemployment or NAIRU ${ }^{1}$.) Since 2015Q1, the U-3, or "headline" unemployment rate, has fallen by more than a full percentage point, while quarterly wage growth has been flat, and year-over-year wage growth has actually declined. In the previous three recoveries, during periods involving comparable declines in unemployment leading up to an unemployment trough, quarterly wage growth increased by an average of about one-quarter of a percentage point, and annual wage growth increased by close to a full percentage point (see Figure 2).

There are two basic explanations for this wage growth puzzle: Either the labor market is truly tight, but some structural issue or measurement issue can explain the slow wage growth; or the labor market is not as tight as the headline unemployment rate indicates. ${ }^{2}$ The latter explanation is especially intriguing given the growing evidence that a significant number of U.S. adults are employed in nonstandard or informal work arrangements - such as gig economy jobs - that may not be reflected in official surveys of the labor market. According to our Survey of Informal Work Participation in the Federal Reserve Bank of New York's Survey of Consumer Expectations (SCESIWP), on average in 2015 and 2016 an estimated 34 percent of U.S. adults participated in informal work (excluding survey work). The average informal worker in a typical month dedicated 17 hours to informal work and earned more than $\$ 400$. Nonetheless, roughly 18 percent of those engaged in informal work would have been classified by the Bureau of Labor Statistics (BLS) as not in the labor force.

In this paper we investigate the possibility that informal or gig work embodies an economically significant amount of labor market slack that is not captured in the U-3 unemployment rate and other standard estimates of slack. Using unique data from the SCE-SIWP extending back to early 2015, we find indirect and direct evidence for this hypothesis. First, we examine the relationship between wage inflation and the extent of informal labor at the level of the census division, exploiting variation within and across census divisions since 2015. We find that our measure of informal labor is negatively associated with wage growth, while we observe no significant association between wage growth and the U-3 or U-6 unemployment rate. These results suggest informal work represents added potential labor supply to the formal market that could reduce

\footnotetext{
${ }^{1}$ NAIRU stands for non-accelerating inflation rate of unemployment. It refers to the level of unemployment below which inflation is expected to increase.

${ }^{2}$ For example, Daly and Hobijn (2016) argue that the ongoing wave of baby boomer retirements depresses measured wage growth as older, highly paid workers are replaced by entry-level workers. Sumner (2017) says that slow nominal GDP growth reconciles slow wage growth. Ozimek (2017) argues there is hidden slack in the labor market that is evident in the low labor force participation rate of prime-age individuals. See Scott Sumner, "Slow Wage Growth? There's No Mystery to Explain," The Money Illusion, August 28, 2017. Available at http://www.themoneyillusion.com/?p=32621.
} 
pressure on measured wages, although other interpretations are possible. Our survey also offers direct evidence that informal work can be viewed as slack, because most informal work participants in our survey say that for some increase in pay, they would drop hours of informal work in exchange for added hours of formal work.

Importantly, our estimates of the extent of slack embodied in informal work are economically significant. Measuring in terms of full-time equivalents (FTEs), we estimate that as of 2015-2016 informal labor amounted to 2.2 percent to 5.7 percent of the labor force, depending on the census division. While we do not have current estimates of the informal-FTE share, our results suggest that the low headline unemployment rate may mask a considerable amount of labor market slack, and that monetary policy makers might seek out data on informal work participation as an additional indicator of labor market conditions.

We are confident in our estimates of informal work participation rates, because they are comparable to other recent estimates of nonstandard work that use similar criteria to define such work. For example, a McKinsey report finds that as of mid-2016, 27 percent of the U.S. workingage population had engaged in independent work within the previous year. That report defines independent work as work that entails high worker autonomy, by-task payment, and a short-term relationship between worker and client. Katz and Krueger (2016) examine a related but narrower concept of alternative work and find that alternative workers accounted for 15.8 percent of all employed U.S. adults in 2015, a significant increase over the alternative-worker shares in 2005 (almost 11 percent) and 1995 (10 percent). Consistent with finding an increase in independent work, Katz and Krueger (2016) and Abraham et al. (2016) observe an increase, in recent decades, in the share of individuals filing an IRS Schedule $\mathrm{C}$ tax form, which is used to report earnings or losses from self-employment. Likewise, an analysis of 1099-MISC forms (Dourado and Koopman 2015) — used to report income received outside of traditional employment relationships — indicates an escalation in such filings from 2000 to 2015. These findings support the view of a changing labor market in which informal or nonstandard work is becoming increasingly important (see Figure 3).

In principle, nonstandard work should be captured in the standard measures of employment, such as U-3 and U-6, because these measures intend to capture work activity without regard to the type of work arrangement. Yet findings from our own survey suggest that some portion of informal work is not captured by these measures, which are based on the Current Population Survey (CPS) of the BLS. For example, as seen in Table 1, some 25 percent of unemployed individualsclassified as such based on their responses to CPS questions in our survey - also reported engaging in informal work, and of those classified as not in the labor force, almost 18 percent classified as informal work participants. Furthermore, Bracha and Burke (2016) show that the labor force participation rate in 2015 would have been 2 percentage points higher if informal participants were fully counted as part of the labor force. Among employed individuals, the share classified as 
employed full-time (rather than part-time) would have increased by 4.6 percentage points if informal hours were included. ${ }^{3}$

Because informal work participation seems to have increased over time and yet is not fully captured in household employment surveys, it is possible that standard measures of labor market slack are no longer reliable and therefore are no longer strong predictors of wage growth. We propose the total hours of informal work - expressed in terms of FTEs and taken as a share of the labor force - as an alternative measure of slack. Because the number of informal hours worked varies considerably among informal work participants, using hours enables a calculation of the total amount of informal work being performed in the U.S. economy that is more precise than an informal work participation rate. The SCE-SIWP is the only survey we know of that uses a nationally representative sample of U.S. adults to measure hours spent per individual on informal work.

The central analysis of this paper tests for whether this alternative measure of slack helps explain wage growth in recent times. It does so by using three different waves of the SCE-SIWPconducted in 2015 and 2016-to look at variation in informal hours and wage growth by census division and time period. We use the quarterly percentage change in the Employment Cost Index (ECI) for private wage-and-salary earners as the primary measure of wage growth, but for robustness, we also use alternative measures. As described below, we observe a consistently negative and significant relationship between the informal-FTE share measure and quarterly ECI growth, even after controlling for the quarterly U-3 or U-6 measures, suggesting that additional slack as revealed by higher informal-FTE shares may exert downward pressure on wage growth within a region. This indirect evidence that informal work constitutes slack is then complemented by direct evidence that many individuals who participate in informal work would be willing to supply additional labor to formal jobs if given the opportunity.

The remainder of the paper is organized as follows: Section I describes the SCE-SIWP, in particular how we define informal work participation and how we measure informal work hours. Section II describes the empirical analysis of the relationship between our alternative slack measure and quarterly wage growth based on the ECI. Section III describes our direct survey evidence that informal work embodies labor market slack. Section IV describes our estimates by census division of the extent of slack embodied in informal work under two different conditions. Section V discusses robustness analysis. Section VI concludes the paper with a discussion of how to interpret our findings and discusses possible policy implications.

\section{The Survey of Informal Work Participation (SCE-SIWP)}

The SIWP is an annual special module within the NY Fed Survey of Consumer Expectations (SCE), which is representative of the U.S. adult population for most demographic dimensions,

\footnotetext{
${ }^{3}$ For more details on these results see Bracha and Burke (2016).
} 
including age and gender. The SIWP has three major blocks of questions. The first block is related to general household size, self-reported employment status, available savings, et cetera. The second asks about informal work (paid) activities including engagement in such activities, hours of work, income earned, and how informal pay relates to formal pay for each individual who works informally. The third block is a subset of the CPS employment status questions that allows us to estimate each respondent's employment status according to the criteria used by the BLS. It includes, for instance, the CPS questions "LAST WEEK, did you do ANY work for either pay or profit?" and (for those who did not work) "Have you been doing anything to find work during the last 4 weeks?"

The three waves of the survey were administered in January 2015 ( $\mathrm{N}=1,209)$, December 2015 $(\mathrm{N}=1,058)$, and December $2016(\mathrm{~N}=1,151)$. After removing self-described retirees, those who reported more than $\$ 600,000$ in annual individual income, and those missing important information, we are left with 695 respondents for the January 2015 survey wave, 690 for December 2015, and 843 for December 2016. The main results presented here pertain to this restricted sample, which applies the same criteria used to select the analysis sample in our previous, in-depth study of informal work (Bracha and Burke 2016). For robustness, we replicated the analysis on a broader sample that included all individuals who responded to the main informal work questions and who reported their state of residence, minus a few observations with extreme values for informal earnings and/or hours that were also excluded from our main analysis sample. ${ }^{4}$ The results pertaining to this broader sample are provided in the Appendix.

The two main survey questions used to measure informal work participation are presented below. Figure 4 presents the question asking about current engagement in informal paid activities or side jobs. The question lists various potential activities, including traditional side jobs such as babysitting and new jobs such as driving for Uber or renting out properties on Airbnb. Respondents could also enter side jobs not included in the list.

Respondents received follow-up questions for each type of informal work activity they were currently engaged in, including unlisted activities they specified. The questions asked about hours and income from the given activity and whether they used an app or online platform to perform and/or find the work. An example is given in Figure 5.

In the broader of our two measures of informal work participation, a respondent is considered an informal worker if he or she (1) indicated working in at least one informal paid activity other than survey work, and (2) reported strictly positive hours of informal work when summed across all activities except surveys. According to this measure, 34 percent of the individuals in our analysis sample (averaged over the three survey waves) are classified as participants. To focus on informal activities that do not primarily involve monetizing the value of assets - for example, renting out

\footnotetext{
${ }^{4}$ To be included in the broader sample, respondents had to complete the informal work questions shown in Figures 4 and 5 just below, and they had to indicate their state of residence. Also, we excluded a total of 53 observations in which subjects reported $\$ 8,000$ or more in total monthly earnings from informal work (summed across all relevant activities) and/or reported 365 or more total monthly hours of informal work. We removed these same outlying observations from our main analysis sample based on the criteria, listed just above, for exclusion from that sample.
} 
one's apartment on Airbnb or selling one's possessions on eBay-we construct a narrower definition of participation that restricts informal workers to those who engage in at least one informal paid activity that is not survey work and not a renting/selling activity. Under this preferred definition, which focuses on those who earn informal income from their labor rather than their physical capital, we find that on average, across survey waves, 19 percent are informal workers. Those workers dedicate an average of 24 hours per month to informal work and earn an average of $\$ 370$ per month from such activities.

Informal workers are found in all the employment categories used by the BLS. Recall that we can approximate the BLS employment status of our respondents because we include a subset of the questions from the CPS and use the answers to determine that status. Based on our preferred definition of an informal worker, more than 19 percent of employed individuals classify as informal workers. Twenty-five percent of the unemployed and 17 percent of those not in the labor force also classify as informal workers. At 30 percent, the informal-work participation rate among individuals employed on a part-time basis is especially high.

\section{The Relationship between Wage Inflation and Informal Work}

In the first instance, we measure wage inflation by census division using the over-the-quarter percentage change in the ECI for private wage and salary workers in each division, where the terminal quarter corresponds to a survey date of the SCE-SIWP. For example, for our December 2015 survey wave we assign percentage changes in the non-seasonally adjusted ECI (by census division) between 2015Q3 and 2015Q4. We use non-seasonally adjusted values of the ECI — and non-seasonally adjusted values for all other variables in the analysis - because our survey data are not seasonally adjusted. We use quarterly wage growth measures rather than year-over-year measures based on the supposition that the "current" informal labor supply we measure is likely to be highly flexible by nature and might contribute to high-frequency movements in wages. Moreover, using the year-on-year percentage changes in the ECI leads to a fragile and possibly distorted wage-growth pattern in New England during this time period. We discuss this issue further below. To control for persistent shocks to wage growth that might confound the relationship between informal work participation and current wage growth, we also control for the four-quarter change in the ECI ending in the preceding quarter. For example, when using data from our December 2015 survey, we control for the year-over-year percent change in the ECI (by census division) to 2015Q3.

To test for a relationship between wage growth and traditional measures of unemployment, we include, in various regression models, the quarterly U-3 unemployment rate or the quarterly U-6 unemployment rate by census division. A given quarterly unemployment rate represents the unweighted average of the three monthly unemployment rates for that quarter and that census division. A given monthly unemployment rate by census division represents the weighted average of the monthly state-level unemployment rates for all states in that division. (The weight for a given state equals the size of its labor force as a percentage of the total labor force size for the 
relevant census division.) We use the non-seasonally adjusted unemployment rates from the Local Area Unemployment Statistics produced by the BLS.

As described briefly above, our alternative measure of labor market slack represents an estimate of the total number of FTEs of informal work as a percentage of the size of the labor force. This measure will be referred to as the "informal-FTE share," or just "FTE share" for short. To calculate the informal-FTE share for a given census division and survey period, we use our measures of informal participation and average monthly informal work hours from the relevant survey, and we scale these up to the aggregate census division level using the following formula:

$$
\text { FTE share }=\frac{\left(\begin{array}{c}
\% \text { participation in } \\
\text { informal work }
\end{array}\right) \times\left(\begin{array}{c}
\text { average hours } \\
\text { of informal work }
\end{array}\right) \times\left(\begin{array}{c}
\text { adult } \\
\text { population }
\end{array}\right)}{160 \times\left(\begin{array}{l}
\text { labor } \\
\text { force }
\end{array}\right)}
$$

It should be understood that each component in the formula is measured for a given census division - based on geographic identifiers in our survey — and a given survey period. The product of the first and third terms in the numerator - the informal participation rate and the adult population-gives the expected absolute number of people engaging in informal work for the given census division and time period. Multiplying this result by the average number of informal work hours (among participants) gives the expected total number of informal work hours supplied by the adult population in the given division; dividing this latter number by 160 - the number of hours of full-time work per month based on a four-week month-expresses the total number of informal work hours in terms of FTEs. Dividing by the size of the labor force enables comparisons across census divisions and over time, and it also results in a measure that is comparable to other labor market indicators such as the unemployment rate.

We also use a more conservative measure that involves the participation rate and average hours of informal work among only those classified as in the labor force:

$$
\text { FTE share_conservative }=\frac{\left(\begin{array}{c}
\% \text { participation in } \\
\text { informal work } \\
\text { por people in the LF }
\end{array}\right) \times\left(\begin{array}{c}
\text { average hours } \\
\text { of informal work } \\
\text { for people in the LF }
\end{array}\right) \times\left(\begin{array}{l}
\text { labor } \\
\text { force }
\end{array}\right)}{160 \times\left(\begin{array}{l}
\text { labor } \\
\text { force }
\end{array}\right)}
$$




\section{Results}

The data we use forms a panel of the nine census divisions over the three survey waves, with a total of 27 observations. In Table 2 we run a simple regression using the conservative FTE share measure, controlling for time and the preceding quarter's year-to-year percentage change in ECI, and using division fixed effects. Table 3 presents the results of first-difference regressions, again using the conservative FTE-share measure. The results from using the measure of the FTE share scaled up to the U.S. adult population are very similar and are presented in the Appendix.

As the results in Table 2 and 3 show, wage inflation has no significant relationship with the U-3 or U-6 unemployment rate, but it does have a significant relationship — a negative one - with the informal-work FTE share. This negative relationship between the informal-work FTE share and wage inflation also holds when we control for the U-3 or U-6 unemployment rate. It also remains when we use the FTE-share measure scaled up to the U.S. adult population, and when we use the larger sample described above, which consists of nearly all the respondents who have the necessary information to run these regressions. These results are presented in the Appendix.

The negative relationship between wage inflation and the informal-FTE share can be seen in the bottom two scatter plots in Figure 6, whereas the top plots reveal the flat relationships between ECI growth and U-3 or U-6. However, because New England exhibits an extreme quarterly ECI change in 2015Q1, we create separate scatter plots, in Figure 7, that exclude all the observations from New England. The negative relationship between wage growth and the informal-FTE share becomes even more evident in this case. We also conduct the regression analysis excluding New England and find that our initial results are robust. This exercise is shown in the Appendix.

\section{Does Informal Work Represent Slack?}

While the negative relationship is consistent with informal work representing slack, that is, a substitute for formal work, it does not rule out other possibilities. For example, the market for informal work might constitute a separate, disjoint labor market, in the sense that workers might not view formal and informal work as substitutes. To further examine whether informal work represents slack, we look at a direct question-contained in only the December 2016 survey wave - that asks about the substitutability of informal hours for formal hours conditional on a certain pay relationship. ${ }^{5}$ If informal work represents slack, we would expect large substitutability

\footnotetext{
${ }^{5}$ We also examine another question from a New York Fed special module to the SCE that asks about job search behavior. If informal work represents slack, we would expect to see that informal workers are more likely than others to report searching for additional jobs. Although we cannot report the details here because the data have not yet been made public, we find support for the slack hypothesis in the fact that the search rate for additional jobs is higher among informal workers than among non-informal workers.
} 
between informal and formal work hours, especially if formal work pays as well as or better than informal work.

\section{Question on Substitutability between Formal and Informal Work}

In the December 2016 survey wave we asked how likely informal workers are to switch an informal hour for formal hour, given a certain pay relationship (see Figure 8).

We aggregate the results to a two-way split where (1) the offered pay in the formal job is less than in the informal work, and (2) the offered pay in the formal job is greater than in the informal work. The results are in Figure 9. Panel (a) of Figure 9 shows the aggregate result for all informal workers; panel (b) presents the same results, by labor force participation status.

The results show that the majority are likely (whether somewhat likely or very likely) to switch informal hours for formal hours if the formal pay is as much as or greater than the informal pay. Even when the formal pay offer is less than the informal pay, about 26 percent still would likely switch an informal hour to a formal hour of work.

We find similar results regardless of one's labor force participation status: The majority would switch to formal work if it pays as well as or better than the informal hour. The difference is that the majority of informal workers who are not in the labor force would also switch an informal hour to a formal hour when the formal pay is less than the informal pay.

When asked about how their actual pay from informal work compares to their formal pay, the majority of individuals responded that they earn less in informal work, and the largest share reported that, from their informal paid activities, they earn less than half of what they make from their formal work (see Figure 10). That is, in the relevant switching-question scenarios, the informal pay is lower than the offered formal pay, and the majority (regardless of official labor force status) would switch informal for formal work.

These results are consistent with informal work's representing slack. Indeed, the question assumes the formal work includes schedule flexibility, which may not be the case for many individuals. Nevertheless, many individuals have some flexibility in their formal work schedule, as more and more companies turn to a work-from-home model to save on office space. Even though our survey question posed hypothetical choices that may not fully capture the real-world choices facing informal workers, the responses indicate intentions to substitute formal for informal work.

\section{Magnitude of the Informal-FTE Share}

It is important to assess the absolute magnitudes of the informal-FTE shares obtained in our analysis. If the FTE shares were very small in relation to the labor force, we might doubt whether they could have any effects on wage growth. Taking averages within each census division across

the three survey waves, we find that these shares are in fact economically significant—from 2.2 percent to 5.7 percent of the labor force, depending on the census division. If we thought of these 
FTE shares as possible additions to the unemployment rate - that is, "hidden" full-time workers implied by the work individuals reveal they want to supply - they would in all cases represent significant increases in unemployment. Interestingly, there seems to be a divide between census divisions that have recently experienced accelerating wage growth and those that have not. For an illustration of the different wage growth trends in these two sets of census divisions, see Figure 11. "Accelerating" wage-growth divisions are shown in the left panel, and "non-accelerating" wage-growth divisions are shown in the right panel. We find that in the non-accelerating census divisions, the fraction of the informal-work FTEs done for less pay compared to one's formal pay is high. In particular, it is higher than in the accelerating divisions. This difference can be seen in Figure 12. Following this observation, we run regressions similar to those described above, but we do so using the FTE shares based on only informal hours among those with informal pay that is less than formal pay. ${ }^{6}$ The results are in Tables 4 and 5, and they are similar to the results found before.

\section{Robustness Checks}

We conducted several checks to assess the robustness of our results to alternative methodological choices. We imposed fewer sample restrictions, used the alternative formula for the FTE share based on the entire adult population, used four-quarter changes in the ECI consistently in our firstdifference regressions, and excluded wage growth data for New England.

\section{New England:}

The ECI for New England experienced a steep increase in 2015Q1 compared to the previous quarter, and then it declined sharply in 2015Q2. Given this spike, we determine that New England exhibits an outlying value of the quarterly percentage change in the ECI in 2015Q1. While the scatter plots in Figure 7 suggest that the negative relationship between the informal-FTE shares and wage growth is robust to excluding all observations from New England, we also repeat the regression analysis excluding those observations. The results are in Tables A1-A3 in the Appendix and are similar to those described above.

\section{Unrestricted Sample:}

We repeat the regression analysis using the conservative FTE measure presented in the text, but we use a sample of nearly all the respondents for whom we observe the minimum information needed to conduct the analysis. As described above, this sample includes all individuals who answered the informal work questions and have state information, minus 53 outliers who reported 365 or more monthly informal hours and/or $\$ 8,000$ or more in monthly informal earnings. This sample consists of a total of 2,913 respondents divided roughly evenly among our three sample waves ( $\mathrm{N}=915, \mathrm{~N}=913$, and $\mathrm{N}=1,085$ for January 2015, December 2015, and December 2016,

\footnotetext{
${ }^{6} \mathrm{We}$ determine whether informal pay is less than or greater than formal pay by asking individuals directly how their average pay for informal work compares to what they do earn or could earn in a formal job.
} 
respectively). The results are in Appendix Tables A4-A6. Based on this alternative sample, Figure A1 shows the informal-work-FTE shares by census division, split between accelerating and nonaccelerating divisions. As with our main results, we observe a negative relationship between the informal-FTE shares and quarterly wage growth that is statistically significant in two of the three regression models. We also note that in Figure A1, as in Figure 12, the share of informal FTEs with lower informal pay is uniformly higher in the non-accelerating census divisions.

\section{Adult Population FTE Share Calculation:}

Throughout the analysis we have used the conservative FTE-share formula, which scales up the amount of informal work to the size of the labor force. However, as described above, there is an alternative formula that scales informal work up to the size of the entire U.S. adult population. We repeat the regression analysis using this alternative formula and obtain similar results. These can be seen in Appendix Tables A7-A9. Figure A2 shows the informal-work-FTE shares by census division when we use this alternative calculation, and it exhibits a pattern similar to those in Figure 12 and Figure A1.

\section{First Differences:}

In the first-difference models above, we used raw changes in the informal-FTE shares across successive waves of our survey and matched them with raw differences in the ECI (by census division) over the same time period. For example, for the differences in FTE shares from January 2015 to December 2015, we matched changes in the ECI from 2015Q1 to 2015Q4. For differences in FTE shares from December 2015 to December 2016, we matched differences in the ECI from 2015Q4 to 2016Q4. To address the concern that we used three-quarter ECI changes in some cases and four-quarter changes in others, we also ran first-differences regressions using four-quarter changes in the ECI in all cases. In particular, we instead matched the ECI differences from 2014Q4 to 2015Q4 to the differences in informal-FTE shares from January 2015 to December 2015, and otherwise made no changes. We ran these models using both types of FTE-share calculations, and in all cases we observed negative relationships, although these are statistically insignificant. The results are in Appendix Tables A10-11.

\section{Concluding Remarks}

This paper presents evidence of a negative relationship between the labor hours embodied in informal work and wage inflation, as well as evidence that most informal work participants view informal and formal work as substitutes for each other. While the evidence should be taken with caution given the limited number of observations available, it nevertheless suggests that informal work represents a significant component of the labor market that may reveal hidden information about slack. In particular, our evidence suggests that this measure of slack-unlike the U-3 or U6 unemployment rate- - helps to explain why wage inflation is faster in some census divisions than others. Furthermore, census divisions with relatively weak wage inflation also tend to have more 
"low-wage" informal FTE - that is, more hours of informal work performed at a wage that is less than formal pay.

There are reasons why some individuals may prefer to work informally, with schedule flexibility being a main attraction. In the direct question asking about substitutability (in the last survey only, in December 2016), we ask respondents to assume they could choose when to work in a hypothetical formal job. Because many formal jobs do not offer such flexibility, the willingness to switch to formal work that we observe may be exaggerated relative to real-world conditions. Nevertheless, the responses suggest some aspiration or preference for formal jobs among many respondents. Furthermore, many companies offer some degree of scheduling flexibility as well as the option to work from home at least some of the time.

While we observe a negative relationship between informal work and wage inflation, we cannot pin down the exact mechanism by which this occurs. It is possible that informal work represents labor market slack and therefore puts downward pressure on wages. If so, central bankers might want to keep tabs on informal work activity as a measure of slack in order to help forecast wage growth. However, it is also possible that causality runs in the other direction: Given weak wage growth, individuals seek out other work opportunities to earn sufficient income. While this latter explanation doesn't necessarily imply that informal work represents slack, it nonetheless indicates a kind of labor market weakness, whereby many individuals feel insufficiently employed despite the low aggregate unemployment rate.

Alternatively, there are potential structural explanations for a relationship between informal labor and wage growth. For example, some recent news articles and blog posts have suggested that structural increases in firms' reliance on lower-wage, non-employee work-such as contract work, gig economy jobs, and freelancing — might be responsible for weak wage growth, but the articles and posts don't offer hard empirical evidence to support such claims. ${ }^{7}$ An increased ability to draw on relatively low-wage alternative (non-employee) labor could reduce measured wage growth directly - to the extent that non-employee wages are included in any wage growth measure - or indirectly, by reducing the bargaining power of traditional employees who may now be more readily substituted with contract workers. This structural explanation, while intriguing, begs the question of how firms can manage to recruit enough labor from alternative arrangements amid what looks like a very tight labor market. In other words, we are brought back around to the question of how much slack the labor market really contains. In addition, structural changes are likely to be slow-moving, and therefore they are likely to be incapable of explaining wage growth movements at the quarterly frequency.

\section{Figures and Tables}

\footnotetext{
${ }^{7}$ For example, see Lauren Weber, “The End of Employees," The Wall Street Journal, September 14, 2017. Available at https://www.wsj.com/articles/the-contractors-life-overlooked-ground-down-and-stuck-1505400087. Will Martin, "The Gig Economy Has Created a Strange New Problem in Britain's Labour Market," Business Insider, April 17, 2017. Available at http://www.businessinsider.com/gig-economy-jobs-are-failing-to-stimulate-wage-growth-2017-4.
} 
Figure 1: Wage Growth Philips Curve, Quarterly 1994Q1 to 2015Q1

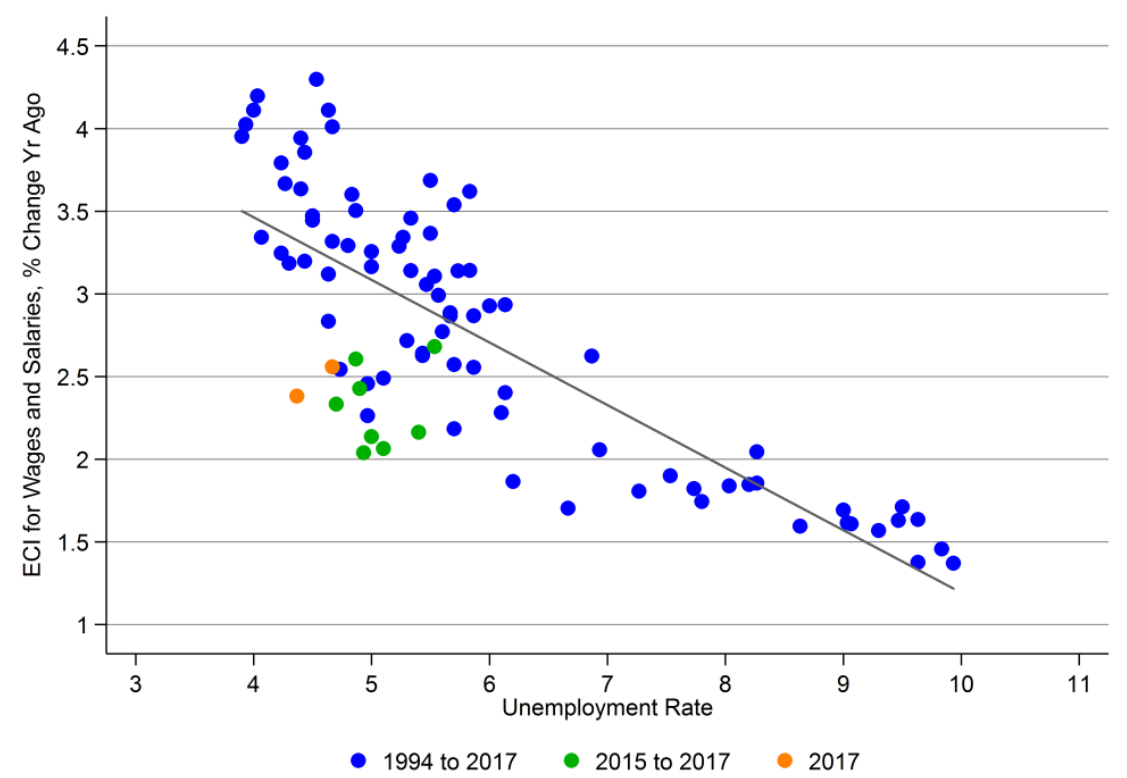

Sources: Bureau of Labor Statistics, Moody's Analytics, Haver Analytics

Figure 2: Quarterly Wage Growth and Unemployment, 1987Q1 to 2017Q2

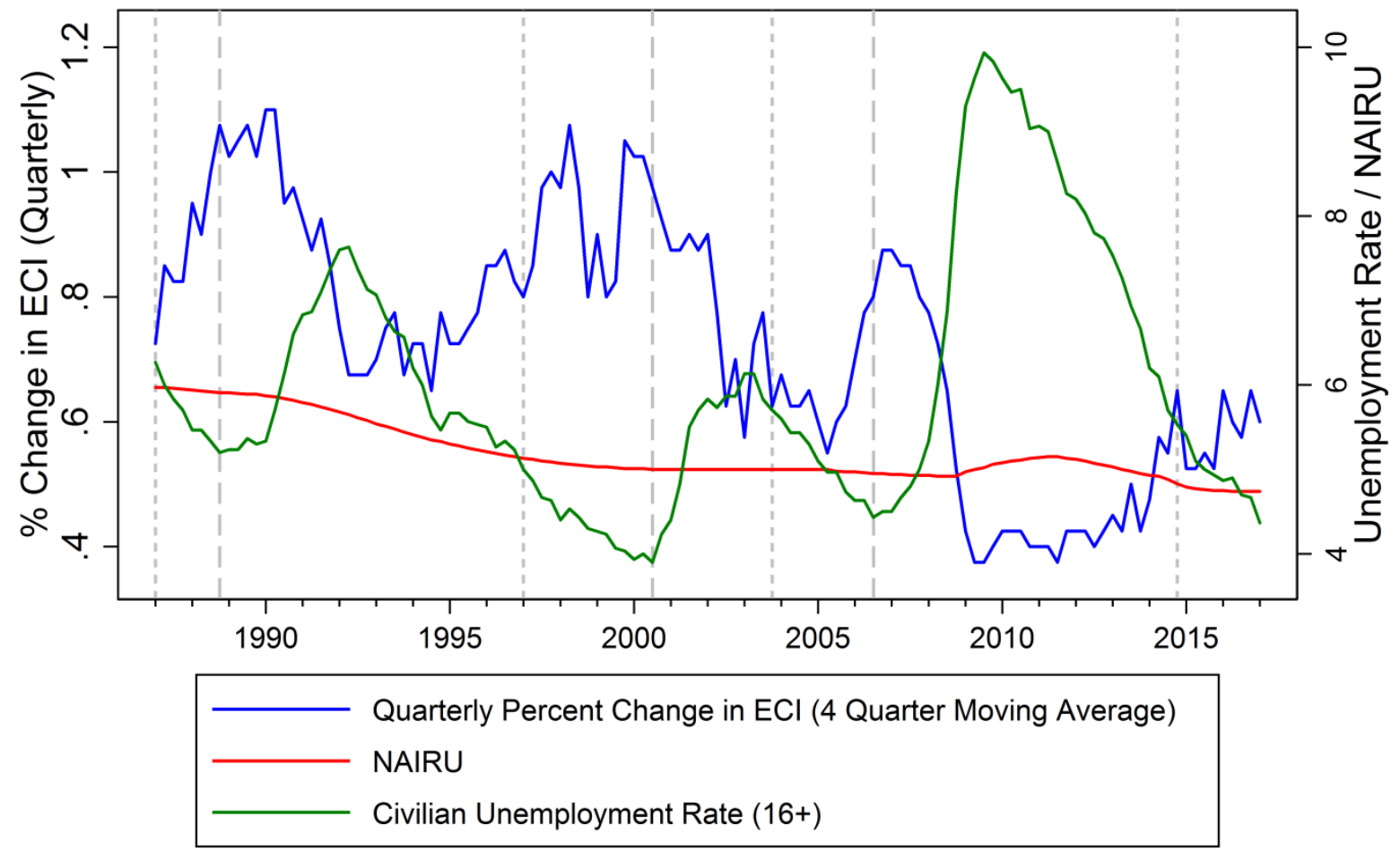

Sources: Bureau of Labor Statistics/Congressional Budget Office; Seasonally Adjusted Data 


\section{Figure 3: IRS Data on Nonstandard Work Filings over Time}

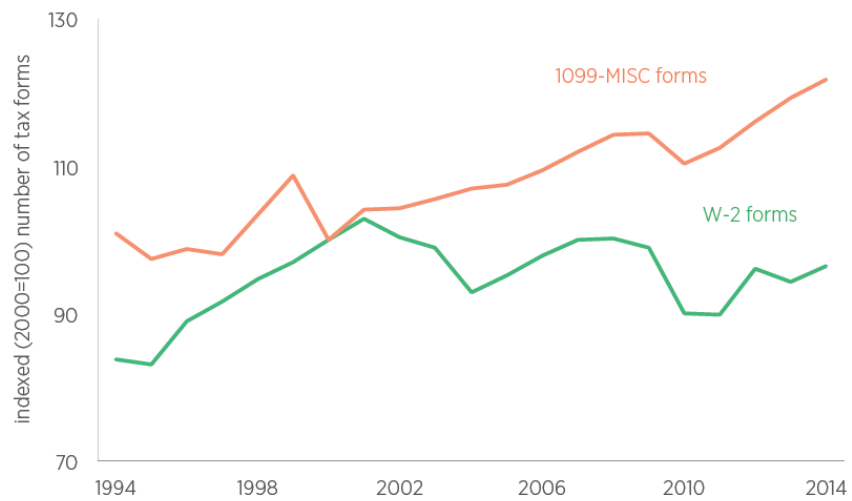

Source: Dourado and Koopman (2015) using IRS data.

Note: Form 1099-MISC is used to report income received outside traditional employment relationships, such as from Uber, TaskRabbit, and Airbnb.

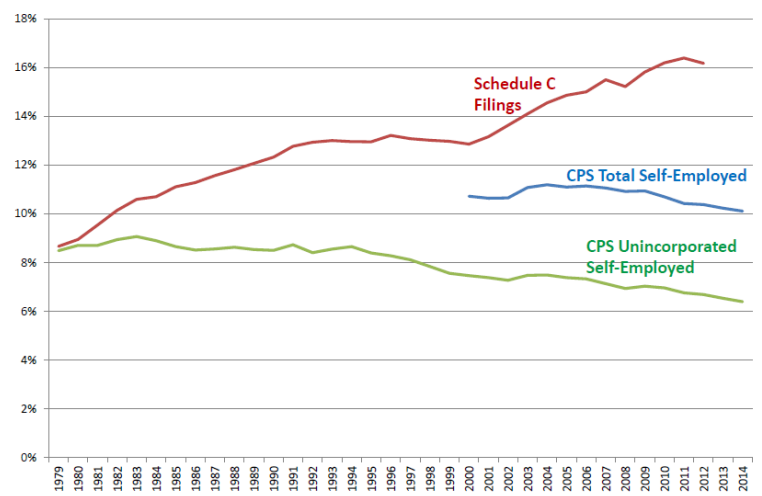

Source: Katz and Krueger (2016) using IRS data.

Note: Schedule C (Form 1040) is used to report earnings or losses from operating business or practicing a profession as a sole proprietor

\section{Figure 4: Informal Work Engagement Question}

\begin{tabular}{|c|c|c|}
\hline & \multicolumn{2}{|c|}{ Are you currently engaged in this activity? } \\
\hline & Yes & No \\
\hline Babysitting & 0 & 0 \\
\hline House sitting & 0 & 0 \\
\hline Dog walking & 0 & 0 \\
\hline Yard or lawn care (i.e., mowing, weeding, etc.) & 0 & 0 \\
\hline Housecleaning & 0 & 0 \\
\hline House painting & 0 & 0 \\
\hline Eldercare services & 0 & 0 \\
\hline $\begin{array}{l}\text { Providing services to other people (for example picking up their dry cleaning, helping people move } \\
\text { houses, running errands, booking travel, or other personal assistance) }\end{array}$ & 0 & 0 \\
\hline Selling goods at consignment shops & 0 & 0 \\
\hline Selling goods on eBay, craigslist, or similar websites & 0 & 0 \\
\hline Renting out property such as your car, your place of residence, or other items you own & 0 & 0 \\
\hline Driving for a ride sharing service like Uber, Lyft, or Sidecar & 0 & 0 \\
\hline Responding to surveys, including phone surveys, online surveys, and in-person surveys & 0 & 0 \\
\hline $\begin{array}{l}\text { Getting paid to complete tasks online through websites such as Amazon Mechanical Turk, Fiverr, or } \\
\text { similar sites (examples of such tasks include, but are not limited to, editing documents, reviewing } \\
\text { resumes, writing songs, creating graphic designs, rating pictures, etc.) }\end{array}$ & 0 & 0 \\
\hline $\begin{array}{l}\text { Posting videos, blog posts, or ather content online, such as an YouTube, and receiving pay (including ad } \\
\text { revenues or commissions) as a result }\end{array}$ & 0 & 0 \\
\hline Other informal paid activity or side jobs (please specify) & 0 & 0 \\
\hline
\end{tabular}


Figure 5: Follow up Questions for a Specific Informal Work Activity

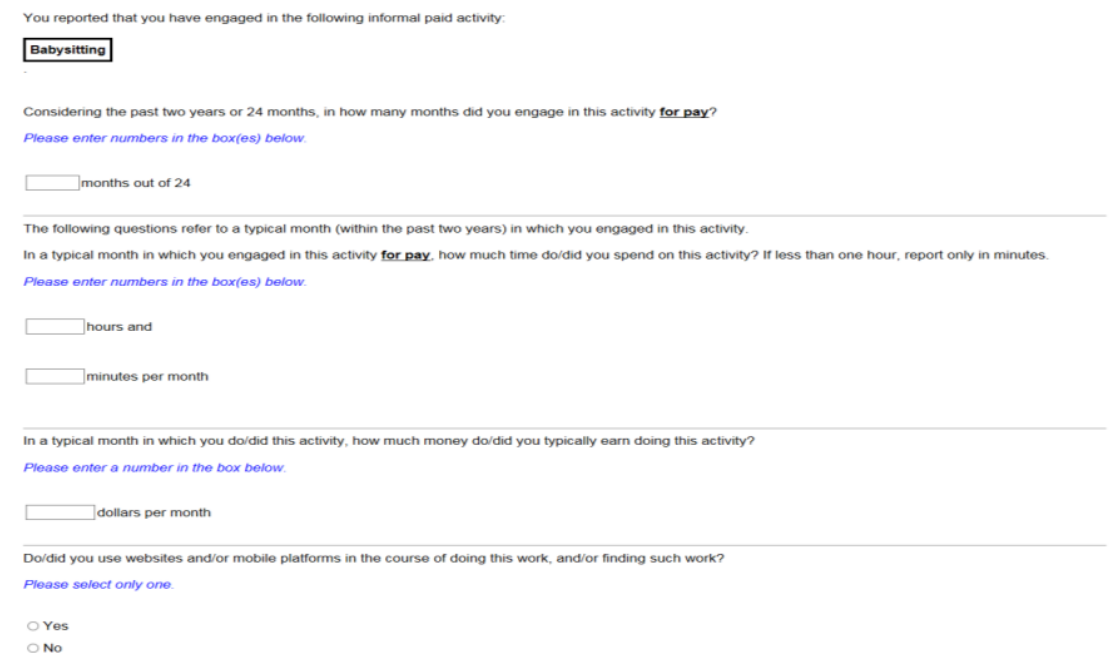

Figure 6: Quarterly Wage Inflation vs. Unemployment Rates and Informal Work FTE Share
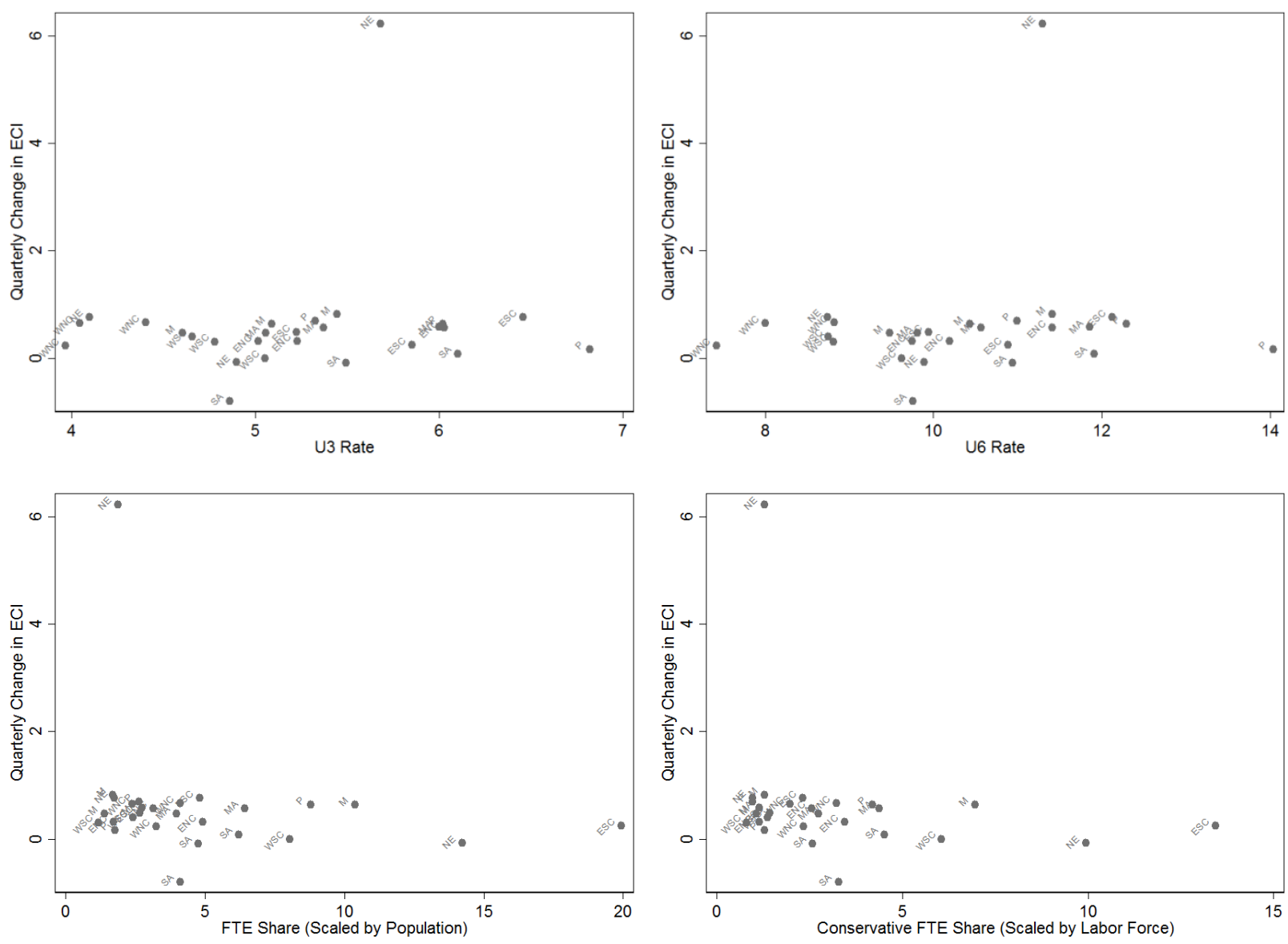
Figure 7: Quarterly Wage Inflation vs. Unemployment Rates and Informal Work FTE Share, Excluding New England
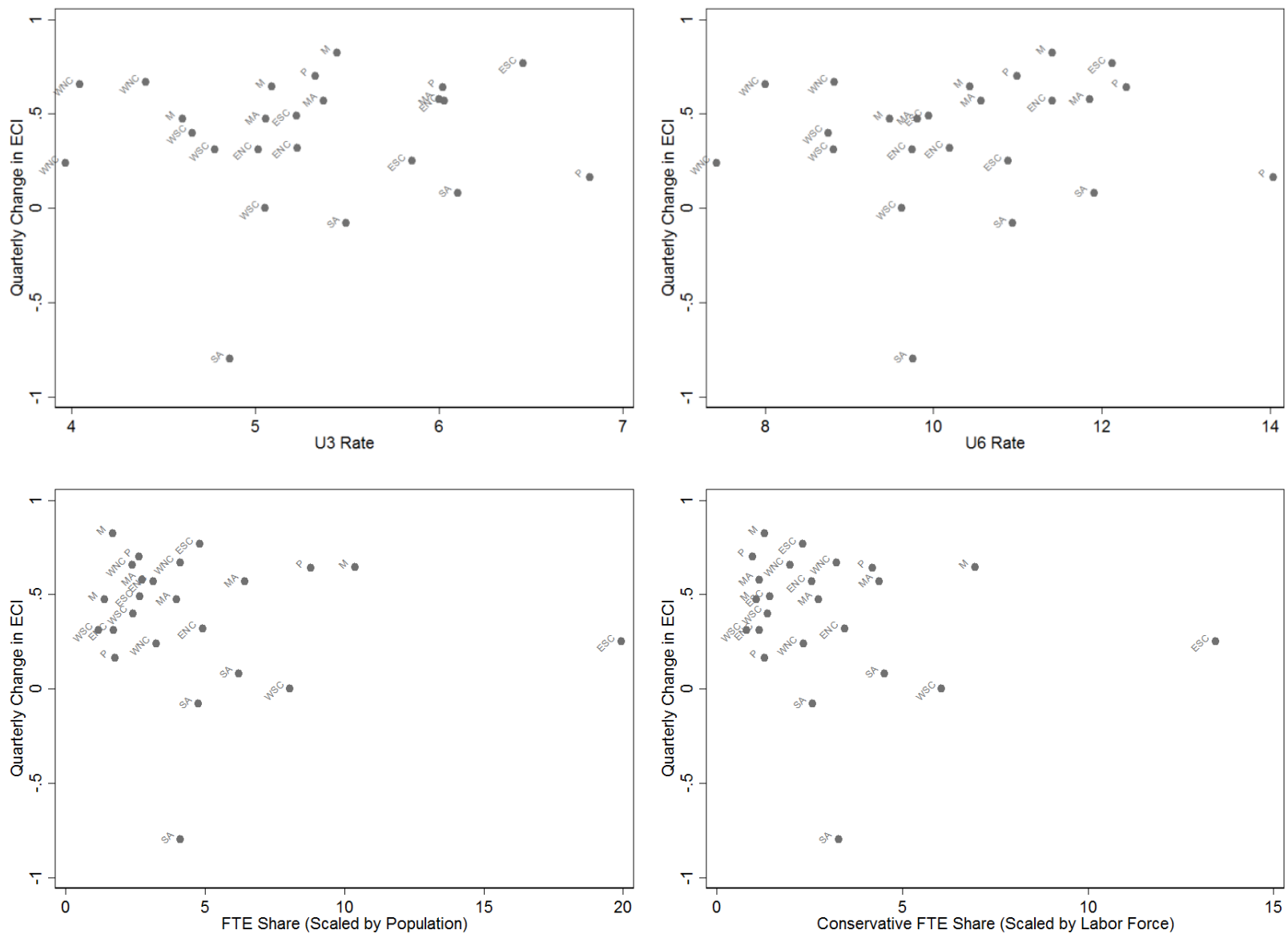


\section{Figure 8: Substitutability Question in the December 2016 SIWP}

Suppose your current employer (or a similar employer) offered you the opportunity to work more hours per week and let you choose when to work them. This offer does not include any benefits (beyond any benefits that you may currently get). How likely would you be to give up informal hours in order to work more hours for this employer if...:

Please select only one.

$\begin{aligned} & \text { The offered pay is more than } 2 \text { times as } \\ & \text { much as the pay you make in a side-job or } \\ & \text { other informal paid work? }\end{aligned}$
$\begin{aligned} & \text { The offered pay is between } 1.5 \text { and } 2 \text { times } \\ & \text { as much as the pay you make in a side-job } \\ & \text { or other paid informal work? }\end{aligned}$
$\begin{aligned} & \text { The offered pay is either equal to or up to } \\ & 1.5 \text { times as much as the pay you make in } \\ & \text { a side-job or other paid informal work? }\end{aligned}$
$\begin{aligned} & \text { The offered pay is between } 1 / 2 \text { as much and } \\ & \text { just below the pay you make in a side-job } \\ & \text { or other paid informal work? }\end{aligned}$
$\begin{aligned} & \text { The offered pay is less than } 1 / 2 \text { as much as } \\ & \text { the pay you make in a side-job or other } \\ & \text { paid informal work? }\end{aligned}$


Figure 9: Likelihood of Switching between Informal and Formal Work Hours

\section{Panel (a): Overall Results}
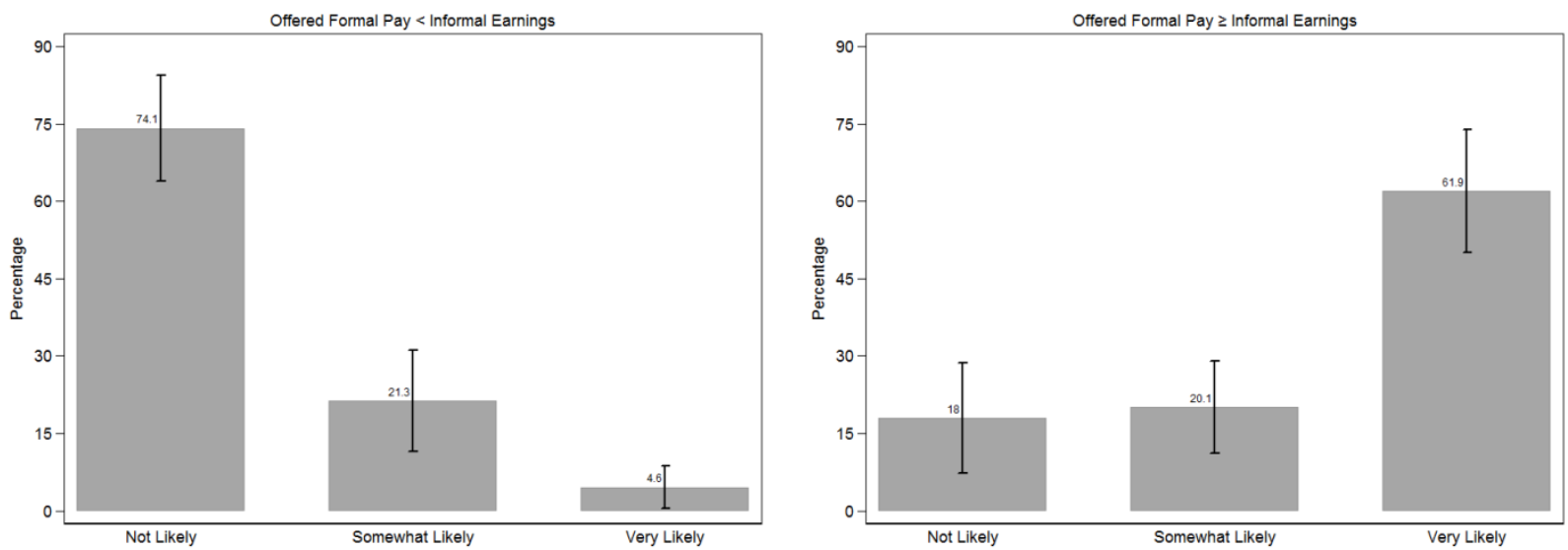

Panel (b): Switching Likelihood, by Labor Force Participation Status
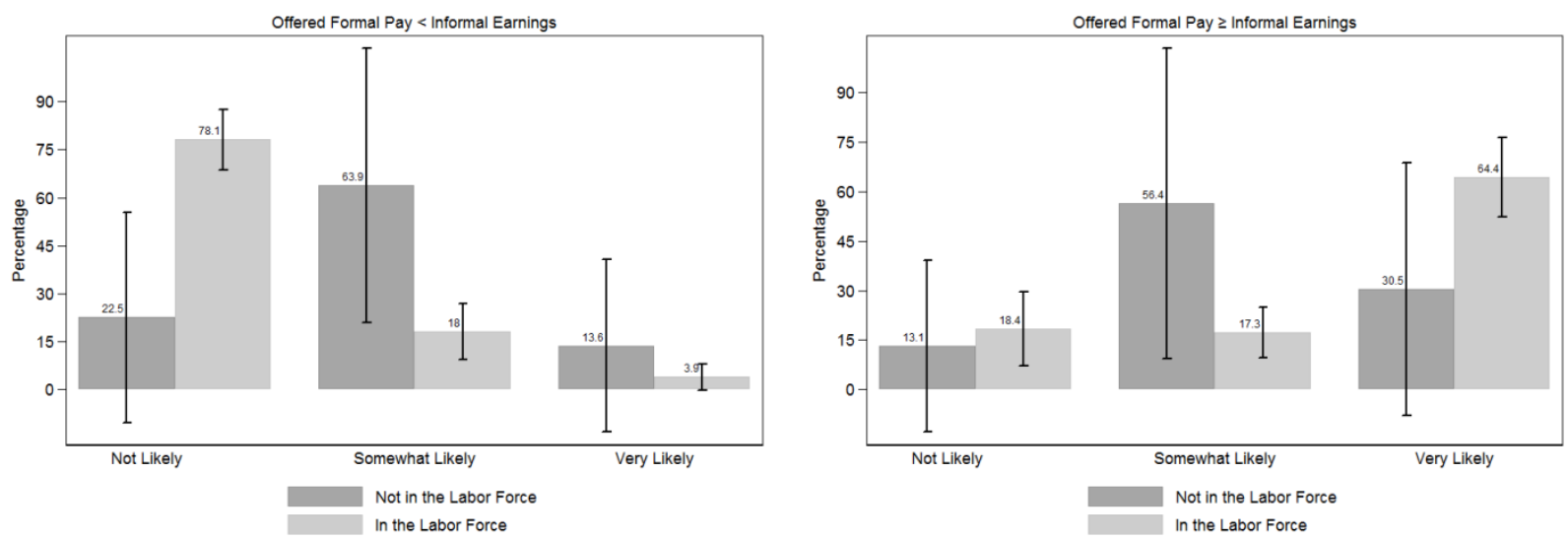

Note: The bar lines indicate a 95 percent confidence interval around each estimated mean.

Figure 10: Comparison of Informal vs. Formal Pay
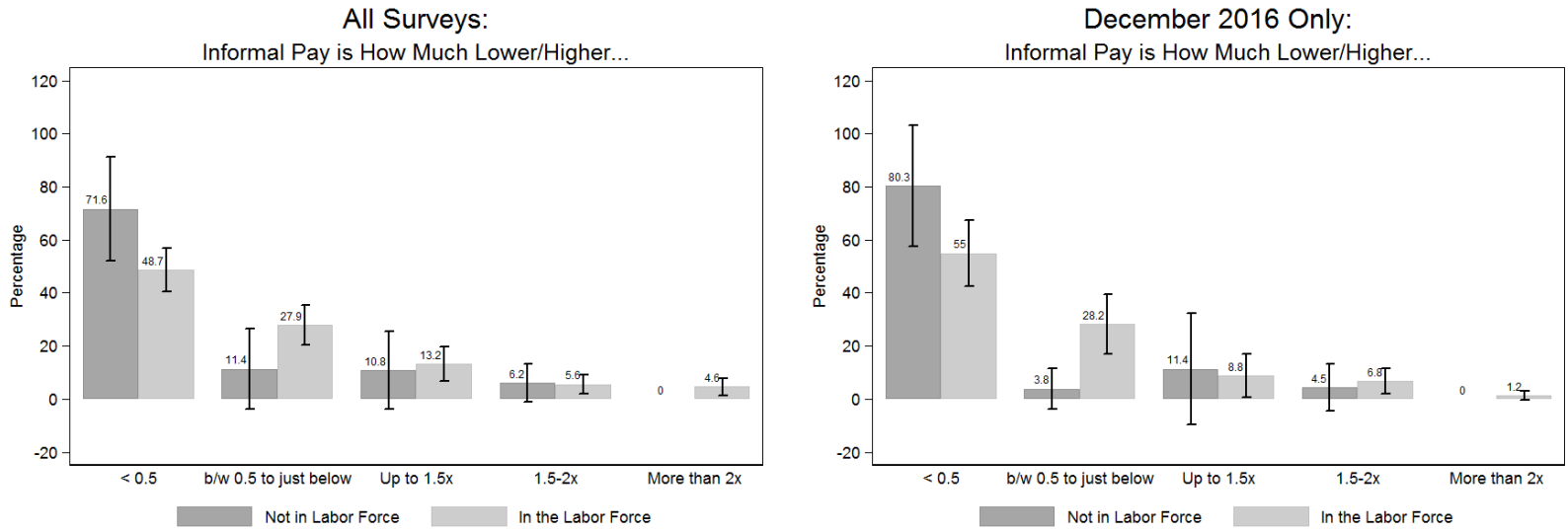

Note: The bar lines indicate a 95 percent confidence interval around each estimated mean. 
Figure 11: Accelerating and Non-Accelerating Wage Growth Census Divisions
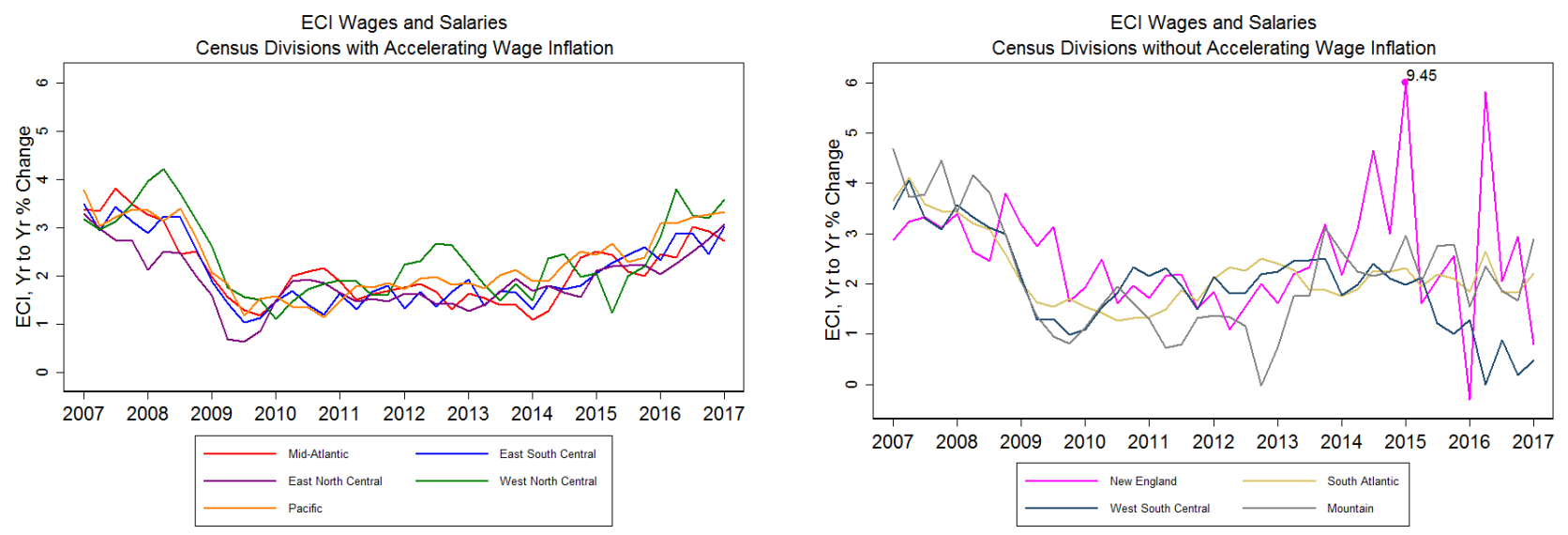

Source: Bureau of Labor Statistics / Haver Analytics

Note: The Yr to Yr \% Change in ECI for Q1 2015 was capped to 6 in order to keep the same scale across both figures.

Figure 12: Informal Work FTE Share, by Census Division and Informal Pay Condition

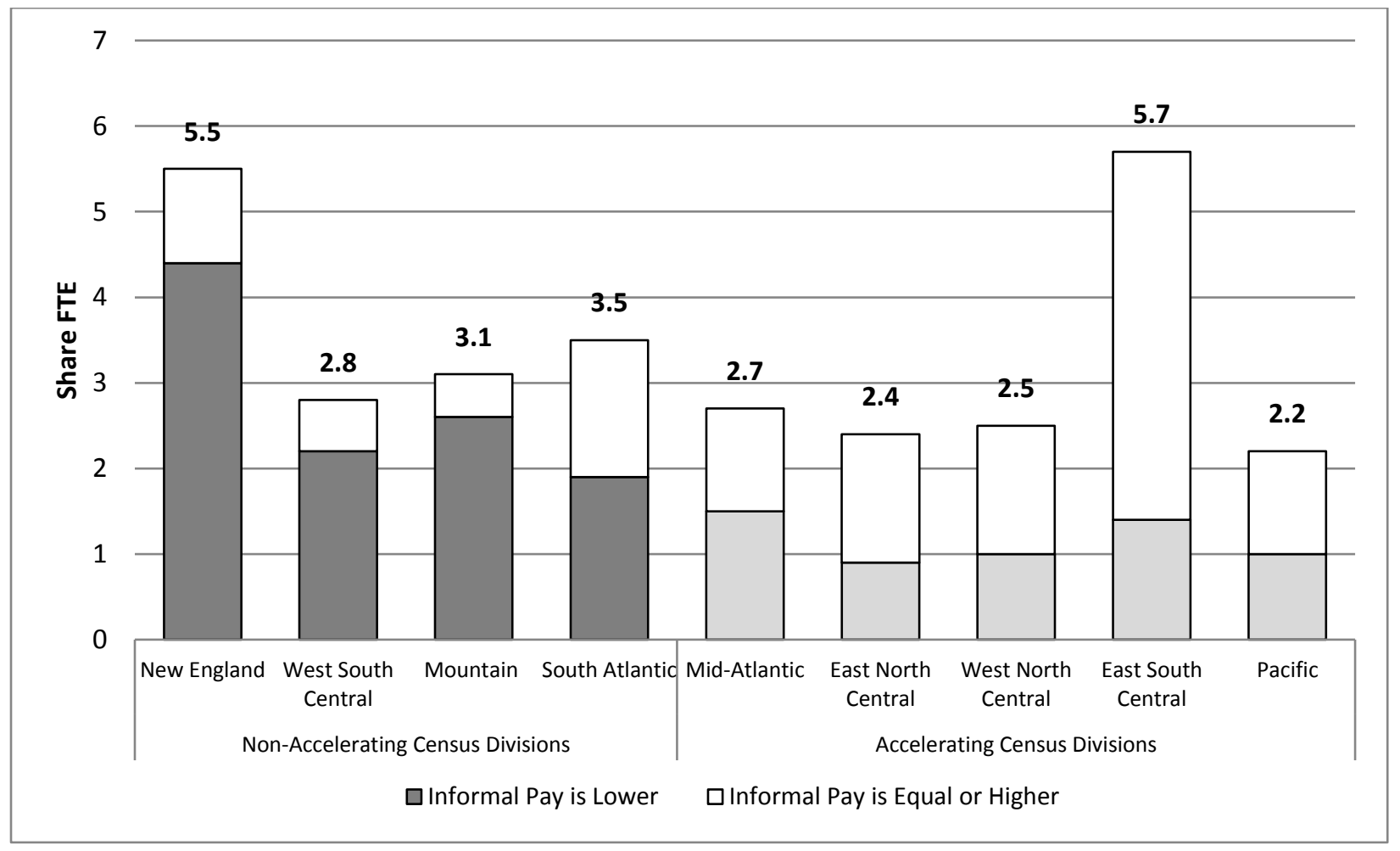


Table 1: Average Informal Work Participation Rate and Hours Worked, by BLS Status

\begin{tabular}{lcccc} 
& \multicolumn{2}{c}{ Employed } & Unemployed & $\begin{array}{c}\text { Not in the Labor } \\
\text { Force }\end{array}$ \\
& Full Time & Part Time & & \\
Informal Participation Rate & $15.9 \%$ & $30.1 \%$ & $24.6 \%$ & $17.5 \%$ \\
Average Monthly Informal Hours & 18.5 & 38.4 & 8.0 & 18.8
\end{tabular}

Table 2: Quarterly Wage Inflation vs. Measures of Unemployment and Informal Work

\begin{tabular}{lccccc}
\hline & $(1)$ & $(2)$ & $(3)$ & $(4)$ & $(5)$ \\
\hline U3 Rate & 0.577 & & & 0.538 & \\
& $(1.35)$ & & & $(1.25)$ & \\
U6 Rate & & 0.218 & & & -0.044 \\
& & $(0.87)$ & & & $(0.82)$ \\
FTE Share & & & $-0.165^{*}$ & $-0.164^{*}$ & $-0.166^{*}$ \\
& & & $(0.09)$ & $(0.09)$ & $(0.09)$ \\
L. YOY ECI Change & 0.804 & 0.880 & $0.983^{*}$ & 0.867 & $0.994^{*}$ \\
& $(0.60)$ & $(0.56)$ & $(0.47)$ & $(0.55)$ & $(0.52)$ \\
Constant & -3.992 & -3.310 & -0.618 & -3.472 & -0.142 \\
& $(7.27)$ & $(9.57)$ & $(1.09)$ & $(6.73)$ & $(9.04)$ \\
Time Control & Yes & Yes & Yes & Yes & Yes \\
\hline Census Division Count & 27 & 27 & 27 & 27 & 27 \\
\hline
\end{tabular}

Note: Fixed-effect linear model. The dependent variable is the quarterly change in ECI by census division and time period, and the explanatory variables are the corresponding unemployment measures or informal-work FTE share, and the preceding quarter's year-to-year ECI change. Model includes time controls and census division fixed effects. Share of FTE calculation is based on informal participation and hours among respondents classified to be In the Labor Force. Standard errors in parentheses. ${ }^{*} p<0.10,{ }^{* *} p<0.05,{ }^{* * *} p<0.01$

Table 3: First Difference in Wage Inflation vs. Measures of Unemployment and Informal Work

\begin{tabular}{|c|c|c|c|c|c|}
\hline & (1) & $(2)$ & (3) & (4) & $(5)$ \\
\hline D.U3 Rate & $\begin{array}{l}2.737 \\
(1.74)\end{array}$ & & & $\begin{array}{l}2.549 \\
(1.49)\end{array}$ & \\
\hline D.U6 Rate & & $\begin{array}{l}1.825 \\
(1.14)\end{array}$ & & & $\begin{array}{l}1.183 \\
(1.07)\end{array}$ \\
\hline D.FTE Share & & & $\begin{array}{c}-0.186^{* *} \\
(0.07)\end{array}$ & $\begin{array}{c}-0.180^{* *} \\
(0.07)\end{array}$ & $\begin{array}{c}-0.162^{* *} \\
(0.08)\end{array}$ \\
\hline Constant & $3.494^{* * *}$ & $3.920^{* * *}$ & $2.025^{* * *}$ & $3.310^{* * *}$ & $3.205^{* *}$ \\
\hline & $(0.98)$ & $(1.21)$ & $(0.41)$ & $(0.85)$ & $(1.14)$ \\
\hline Census Division Count & 18 & 18 & 18 & 18 & 18 \\
\hline
\end{tabular}

Note: OLS regression analysis. The dependent variable is the raw difference in ECI between consecutive survey waves (2015Q4-2015Q1 and 2016Q4-2015Q4); the explanatory variables are the corresponding differences in the unemployment measures or informal work FTE share. Standard errors in parentheses. ${ }^{*} p<0.10,{ }^{* *} p<0.05,{ }^{* * *} p<0.01$ 


\section{Table 4: Quarterly Wage Inflation vs. Measures of Unemployment and Informal Work: Informal Pay Is Less than Formal Pay}

\begin{tabular}{|c|c|c|c|c|c|}
\hline & (1) & (2) & (3) & (4) & (5) \\
\hline U3 Rate & $\begin{array}{l}-0.451 \\
(0.37)\end{array}$ & & & $\begin{array}{l}-0.438 \\
(0.29)\end{array}$ & \\
\hline U6 Rate & & $\begin{array}{l}-0.233 \\
(0.24)\end{array}$ & & & $\begin{array}{l}-0.285 \\
(0.18)\end{array}$ \\
\hline FTE Share, Lower & & & $\begin{array}{c}-0.094^{* *} \\
(0.03)\end{array}$ & $\begin{array}{c}-0.093^{* *} \\
(0.03)\end{array}$ & $\begin{array}{c}-0.098^{* * *} \\
(0.03)\end{array}$ \\
\hline L. YOY ECI Change & $\begin{array}{l}0.218 \\
(0.17)\end{array}$ & $\begin{array}{l}0.180 \\
(0.16)\end{array}$ & $\begin{array}{l}0.193 \\
(0.13)\end{array}$ & $\begin{array}{l}0.273^{*} \\
(0.13)\end{array}$ & $\begin{array}{l}0.250^{*} \\
(0.13)\end{array}$ \\
\hline Constant & $\begin{array}{l}2.593 \\
(2.02)\end{array}$ & $\begin{array}{l}2.724 \\
(2.66)\end{array}$ & $\begin{array}{l}0.213 \\
(0.27)\end{array}$ & $\begin{array}{l}2.565 \\
(1.59)\end{array}$ & $\begin{array}{l}3.338 \\
(2.04)\end{array}$ \\
\hline Time Control & Yes & Yes & Yes & Yes & Yes \\
\hline Census Division Count & 26 & 26 & 26 & 26 & 26 \\
\hline
\end{tabular}

Note: Fixed-effect linear model. The dependent variable is the quarterly change in ECI by census division and time period, and the explanatory variables are the corresponding unemployment measures or informal-work FTE share with lower informal pay, and the preceding quarter's year-to-year ECI change. Model includes time controls and census division fixed effects. Share of FTE calculation is based on informal participation and hours among respondents classified to be In the Labor Force. An observation for New England in the January 2015 Survey wave is missing due to the lack of respondents with lower informal pay. Standard errors in parentheses. ${ }^{*} p<0.10,{ }^{* *} p<0.05,{ }^{* * *} p<0.01$

Table 5: First Difference in Wage Inflation vs. Measures of Unemployment and Informal Work: Informal Pay Is Less than Formal Pay

\begin{tabular}{|c|c|c|c|c|c|}
\hline & $(1)$ & $(2)$ & (3) & $(4)$ & $(5)$ \\
\hline D.U3 Rate & $\begin{array}{l}1.131 \\
(0.98)\end{array}$ & & & $\begin{array}{l}1.299 \\
(0.99)\end{array}$ & \\
\hline D.U6 Rate & & $\begin{array}{l}0.806 \\
(0.64)\end{array}$ & & & $\begin{array}{l}0.794 \\
(0.64)\end{array}$ \\
\hline D.FTE Share, Lower & & & $\begin{array}{l}-0.075 \\
(0.08)\end{array}$ & $\begin{array}{l}-0.092 \\
(0.08)\end{array}$ & $\begin{array}{l}-0.073 \\
(0.08)\end{array}$ \\
\hline Constant & $\begin{array}{c}3.068^{* * *} \\
(0.54)\end{array}$ & $\begin{array}{c}3.294^{* * *} \\
(0.66)\end{array}$ & $\begin{array}{c}2.472^{* * * *} \\
(0.26)\end{array}$ & $\begin{array}{c}3.094^{* * *} \\
(0.54)\end{array}$ & $\begin{array}{c}3.238^{* * * *} \\
(0.67)\end{array}$ \\
\hline Census Division Count & 17 & 17 & 17 & 17 & 17 \\
\hline
\end{tabular}

Note: OLS regression analysis. The dependent variable is the raw difference in ECI between consecutive survey waves (2015Q4-2015Q1 and 2016Q4-2015Q4), and the explanatory variables are the corresponding differences in the unemployment measures or informal work FTE share with lower informal pay. An observation for New England in the January 2015 Survey wave is missing due to the lack of respondents with lower informal pay. Standard errors in parentheses. ${ }^{*} p<0.10,{ }^{* *} p<0.05$, ${ }^{* * * *} p<0.01$ 


\section{References}

Abraham, Katharine, John C. Haltiwanger, Kristin Sandusky, and James R. Spletzer. 2017.

"Measuring the Gig Economy: Current Knowledge and Open Issues." Available at https://nber15.nber.org/confer/2017/CRIWs17/Abraham_Haltiwanger_Sandusky_Spletzer.pdf.

Bracha, Anat and Mary A. Burke. 2016. "Who Counts as Employed? Informal Work, Employment Status, and Labor Market Slack." Federal Reserve Bank of Boston Working Paper Series No. 16-24.

Daly, Mary and Bart Hobijin. 2016. "The Intensive and Extensive Margins of Real Wage Adjustment." Federal Reserve Bank of San Francisco Working Paper 2016-04. http://www.frbsf.org/economic-research/publications/working-papers/wp2016-04.pdf.

Dourado Eli, and Christopher Koopman. 2015. "Evaluating the Growth of the 1099 Workforce." Mercatus Center, George Mason University.

Katz, Lawrence F., and Alan B. Krueger. 2016. "The Rise and Nature of Alternative Work Arrangements in the United States, 1995-2015." NBER Working Paper No. 22667. Cambridge, MA: National Bureau of Economic Research.

McKinsey Group International. 2016. "Independent Work: Choice, Necessity, and the Gig Economy." Available at http://www.mckinsey.com/global-themes/employment-andgrowth/independent-work-choice-necessity-and-the-gig-economy.

Ozimek, Adam. 2017. "There Is No U.S. Wage Growth Mystery.” Available at https:/www.economy.com/dismal/analysis/datapoints/296127/There-Is-No-US-Wage-GrowthMystery/. Moody's Analytics.

U.S. Department of Labor, Bureau of Labor Statistics. Employment Cost Index by Census Division: Total Compensation: Private Industry Workers; State Unemployment Rates: U-3 and U6; Civilian Labor Force and Population by State. Data retrieved from Haver Analytics. 


\section{Appendix}

\section{A. Excluding New England}

Table A1: Quarterly Wage Inflation vs. Measures of Unemployment and Informal Work

\begin{tabular}{|c|c|c|c|c|c|}
\hline & (1) & (2) & $(3)$ & (4) & (5) \\
\hline U3 Rate & $\begin{array}{l}-0.191 \\
(0.34)\end{array}$ & & & $\begin{array}{c}-0.244 \\
(0.29)\end{array}$ & \\
\hline U6 Rate & & $\begin{array}{c}-0.137 \\
(0.21)\end{array}$ & & & $\begin{array}{c}-0.243 \\
(0.17)\end{array}$ \\
\hline Share FTE & & & $\begin{array}{c}-0.051^{* *} \\
(0.02)\end{array}$ & $\begin{array}{c}-0.052^{* *} \\
(0.02)\end{array}$ & $\begin{array}{c}-0.057^{* *} \\
(0.02)\end{array}$ \\
\hline L. YOY ECI Change & $\begin{array}{l}0.197 \\
(0.14)\end{array}$ & $\begin{array}{l}0.189 \\
(0.14)\end{array}$ & $\begin{array}{l}0.207^{*} \\
(0.11)\end{array}$ & $\begin{array}{l}0.250^{*} \\
(0.12)\end{array}$ & $\begin{array}{c}0.256^{* *} \\
(0.11)\end{array}$ \\
\hline Constant & $\begin{array}{c}1.145 \\
(1.87)\end{array}$ & $\begin{array}{l}1.627 \\
(2.29)\end{array}$ & $\begin{array}{l}0.163 \\
(0.24)\end{array}$ & $\begin{array}{l}1.486 \\
(1.57)\end{array}$ & $\begin{array}{l}2.844 \\
(1.88)\end{array}$ \\
\hline Time Control & Yes & Yes & Yes & Yes & Yes \\
\hline Census Division Count & 24 & 24 & 24 & 24 & 24 \\
\hline
\end{tabular}

Note: Fixed-effect linear model. The dependent variable is the quarterly change in ECI by census division and time period, and the explanatory variables are the corresponding unemployment measures or informal-work FTE share, and the preceding quarter's year-to-year ECI change. Share of FTE calculation is based on informal participation and hours among respondents classified to be In the Labor Force. Model includes time controls and census division fixed effects, excluding New England. Standard errors in parentheses. ${ }^{*} p<0.10,{ }^{* *} p<0.05,{ }^{* * *} p<0.01$

Table A2: Quarterly Wage Inflation vs. Measures of Unemployment and Informal Work: Informal Pay Is Less than Formal Pay

\begin{tabular}{|c|c|c|c|c|c|}
\hline & (1) & (2) & (3) & (4) & (5) \\
\hline U3 Rate & $\begin{array}{l}-0.191 \\
(0.34)\end{array}$ & & & $\begin{array}{c}-0.313 \\
(0.31)\end{array}$ & \\
\hline U6 Rate & & $\begin{array}{l}-0.137 \\
(0.21)\end{array}$ & & & $\begin{array}{l}-0.223 \\
(0.19)\end{array}$ \\
\hline Share FTE, Lower & & & $\begin{array}{c}-0.064 \\
(0.04)\end{array}$ & $\begin{array}{c}-0.071^{*} \\
(0.04)\end{array}$ & $\begin{array}{r}-0.073^{*} \\
(0.04)\end{array}$ \\
\hline L. YOY ECI Change & $\begin{array}{l}0.197 \\
(0.14)\end{array}$ & $\begin{array}{l}0.189 \\
(0.14)\end{array}$ & $\begin{array}{l}0.193 \\
(0.12)\end{array}$ & $\begin{array}{l}0.250^{*} \\
(0.13)\end{array}$ & $\begin{array}{c}0.237^{*} \\
(0.12)\end{array}$ \\
\hline Constant & $\begin{array}{l}1.145 \\
(1.87)\end{array}$ & $\begin{array}{l}1.627 \\
(2.29)\end{array}$ & $\begin{array}{l}0.146 \\
(0.26)\end{array}$ & $\begin{array}{l}1.851 \\
(1.73)\end{array}$ & $\begin{array}{l}2.612 \\
(2.10)\end{array}$ \\
\hline Time Control & Yes & Yes & Yes & Yes & Yes \\
\hline Census Division Count & 24 & 24 & 24 & 24 & 24 \\
\hline
\end{tabular}

Note: Fixed-effect linear model. The dependent variable is the quarterly change in ECI by census division and time period, and the explanatory variables are the corresponding unemployment measures or informal-work FTE share with lower informal pay, and the preceding quarter's year-to-year ECI change. Share of FTE calculation is based on informal participation and hours among respondents classified to be In the Labor Force. Model includes time controls and census division fixed effects, excluding New England. Standard errors in parentheses. ${ }^{*} p<$ $0.10,{ }^{* *} p<0.05,{ }^{* * *} p<0.01$

Table A3: First Difference in Wage Inflation vs. Measures of Unemployment and Informal Work

\begin{tabular}{|c|c|c|c|c|c|}
\hline & (1) & (2) & (3) & (4) & $(5)$ \\
\hline D.U3 Rate & $\begin{array}{l}1.638 \\
(0.97)\end{array}$ & & & $\begin{array}{l}1.565 \\
(0.95)\end{array}$ & \\
\hline D.U6 Rate & & $\begin{array}{l}0.910 \\
(0.62)\end{array}$ & & & $\begin{array}{l}0.739 \\
(0.65)\end{array}$ \\
\hline D.Share FTE & & & $\begin{array}{l}-0.067 \\
(0.05)\end{array}$ & $\begin{array}{l}-0.062 \\
(0.05)\end{array}$ & $\begin{array}{l}-0.051 \\
(0.05)\end{array}$ \\
\hline Constant & $\begin{array}{c}3.209^{* * * *} \\
(0.52)\end{array}$ & $\begin{array}{c}3.310^{* * * *} \\
(0.64)\end{array}$ & $\begin{array}{c}2.408^{* * * *} \\
(0.25)\end{array}$ & $\begin{array}{c}3.141^{* * * *} \\
(0.51)\end{array}$ & $\begin{array}{c}3.120^{* * * * *} \\
(0.67)\end{array}$ \\
\hline Census Division Count & 16 & 16 & 16 & 16 & 16 \\
\hline
\end{tabular}

Note: OLS regression analysis. The dependent variable is the raw difference in ECI between consecutive survey waves (2015Q4-2015Q1 and 2016Q4-2015Q4), and the explanatory variables are the corresponding differences in the unemployment measures or informal-work FTE share among respondents classified to be In the Labor Force. Excluding New England. Standard errors in parentheses. ${ }^{*} p<0.10,{ }^{* *} p<0.05$, ${ }^{* * *} p<0.01$ 
B. Robustness Check: Unrestricted Survey Sample (N=2,913)

Table A4: Quarterly Wage Inflation vs. Measures of Unemployment and Informal Work

\begin{tabular}{|c|c|c|c|c|c|}
\hline & (1) & (2) & (3) & (4) & (5) \\
\hline U3 Rate & $\begin{array}{l}0.577 \\
(1.35)\end{array}$ & & & $\begin{array}{l}0.651 \\
(1.27)\end{array}$ & \\
\hline U6 Rate & & $\begin{array}{l}0.218 \\
(0.87)\end{array}$ & & & $\begin{array}{l}0.032 \\
(0.83)\end{array}$ \\
\hline Share FTE & & & $\begin{array}{c}-0.169 \\
(0.10)\end{array}$ & $\begin{array}{l}-0.171 \\
(0.10)\end{array}$ & $\begin{array}{l}-0.169 \\
(0.10)\end{array}$ \\
\hline L. YOY ECI Change & $\begin{array}{l}0.804 \\
(0.60)\end{array}$ & $\begin{array}{l}0.880 \\
(0.56)\end{array}$ & $\begin{array}{c}1.060^{* *} \\
(0.48)\end{array}$ & $\begin{array}{l}0.920 \\
(0.57)\end{array}$ & $\begin{array}{l}1.052^{*} \\
(0.54)\end{array}$ \\
\hline Constant & $\begin{array}{c}-3.992 \\
(7.27)\end{array}$ & $\begin{array}{l}-3.310 \\
(9.57)\end{array}$ & $\begin{array}{c}-0.718 \\
(1.10)\end{array}$ & $\begin{array}{l}-4.169 \\
(6.83)\end{array}$ & $\begin{array}{r}-1.072 \\
(9.14)\end{array}$ \\
\hline Time Control & Yes & Yes & Yes & Yes & Yes \\
\hline Census Division Count & 27 & 27 & 27 & 27 & 27 \\
\hline
\end{tabular}

Note: Fixed-effect linear model. The dependent variable is the quarterly change in ECI by census division and time period, and the explanatory variables are the corresponding unemployment measures or informal-work FTE share, and the preceding quarter's year-to-year ECI change. Share of FTE calculation is based on informal participation and hours among respondents classified to be In the Labor Force. Model includes time controls and census division fixed effects. Standard errors in parentheses. ${ }^{*} p<0.10,{ }^{* *} p<0.05,{ }^{* * *} p<0.01$

Table A5: Quarterly Wage Inflation vs. Measures of Unemployment and Informal Work: Informal Pay Is Less than Formal Pay

\begin{tabular}{|c|c|c|c|c|c|}
\hline & (1) & (2) & (3) & (4) & (5) \\
\hline \multirow[t]{2}{*}{ U3 Rate } & 0.577 & & & 0.509 & \\
\hline & $(1.35)$ & & & $(1.23)$ & \\
\hline \multirow[t]{2}{*}{ U6 Rate } & & 0.218 & & & 0.015 \\
\hline & & $(0.87)$ & & & $(0.80)$ \\
\hline \multirow[t]{2}{*}{ Share FTE, Lower } & & & $-0.268^{*}$ & $-0.266^{*}$ & $-0.267^{*}$ \\
\hline & & & $(0.13)$ & $(0.13)$ & $(0.14)$ \\
\hline \multirow[t]{2}{*}{ L. YOY ECI Change } & 0.804 & 0.880 & $1.032^{* *}$ & 0.921 & $1.028^{*}$ \\
\hline & $(0.60)$ & $(0.56)$ & $(0.46)$ & $(0.55)$ & $(0.52)$ \\
\hline \multirow[t]{2}{*}{ Constant } & -3.992 & -3.310 & -0.739 & -3.438 & -0.904 \\
\hline & $(7.27)$ & $(9.57)$ & $(1.06)$ & $(6.63)$ & $(8.82)$ \\
\hline Time Control & Yes & Yes & Yes & Yes & Yes \\
\hline Census Division Count & 27 & 27 & 27 & 27 & 27 \\
\hline
\end{tabular}

Note: Fixed-effect linear model. The dependent variable is the quarterly change in ECI by census division and time period, and the explanatory variables are the corresponding unemployment measures or informal-work FTE share with lower informal pay, and the preceding quarter's yearto-year ECI change. Share of FTE calculation is based on informal participation and hours among respondents classified to be In the Labor Force. Model includes time controls and census division fixed effects. Standard errors in parentheses. ${ }^{*} p<0.10,{ }^{* *} p<0.05,{ }^{* * *} p<0.01$

Table A6: First Difference in Wage Inflation vs. Measures of Unemployment and Informal Work

\begin{tabular}{|c|c|c|c|c|c|}
\hline & $(1)$ & (2) & (3) & (4) & $(5)$ \\
\hline D.U3 Rate & $\begin{array}{l}2.737 \\
(1.74)\end{array}$ & & & $\begin{array}{l}2.733^{*} \\
(1.52)\end{array}$ & \\
\hline D.U6 Rate & & $\begin{array}{l}1.825 \\
(1.14)\end{array}$ & & & $\begin{array}{l}1.312 \\
(1.08)\end{array}$ \\
\hline D.Share FTE & & & $\begin{array}{c}-0.187^{* *} \\
(0.08)\end{array}$ & $\begin{array}{c}-0.187^{* *} \\
(0.08)\end{array}$ & $\begin{array}{r}-0.162^{*} \\
(0.08)\end{array}$ \\
\hline Constant & $\begin{array}{c}3.494^{\text {*** }} \\
(0.98)\end{array}$ & $\begin{array}{c}3.920^{* * *} \\
(1.21)\end{array}$ & $\begin{array}{c}1.999^{* * * *} \\
(0.42)\end{array}$ & $\begin{array}{c}3.374^{* * *} \\
(0.86)\end{array}$ & $\begin{array}{c}3.311^{* *} \\
(1.16)\end{array}$ \\
\hline Census Division Count & 18 & 18 & 18 & 18 & 18 \\
\hline
\end{tabular}

Note: OLS regression analysis. The dependent variable is the raw difference in ECI between consecutive survey waves (2015Q4-2015Q1 and 2016Q4-2015Q4), and the explanatory variables are the corresponding differences in the unemployment measures or informal-work FTE share among respondents classified to be In the Labor Force. Standard errors in parentheses. ${ }^{*} p<0.10,{ }^{* *} p<0.05,{ }^{* * *} p<0.01$ 
Figure A1: Informal Work FTE Share, by Census Division and Informal Pay Condition:

\section{Unrestricted Sample}

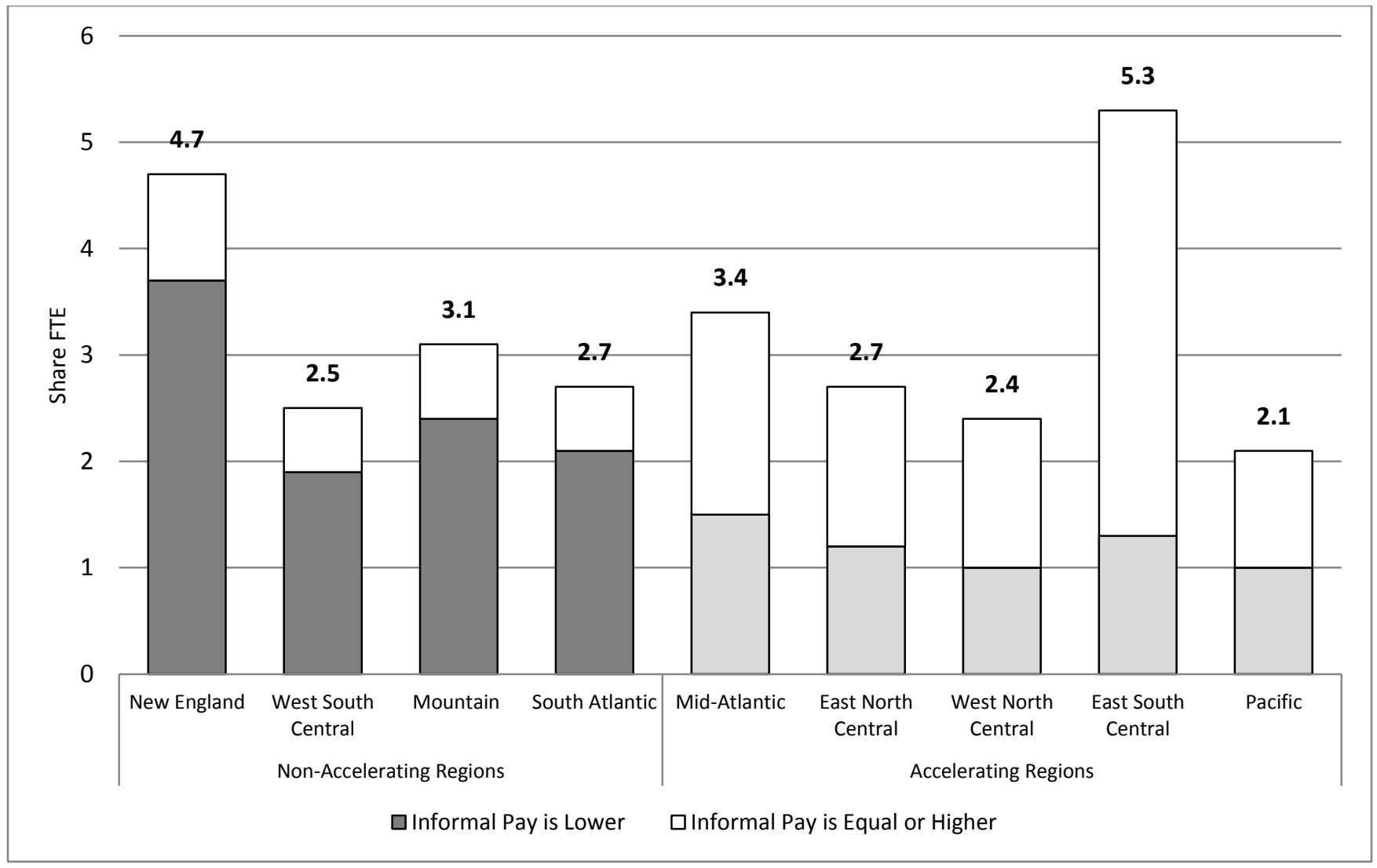


C. Robustness Check: Alternative FTE Shares Scaled to U.S. Adult Population

Table A7: Quarterly Wage Inflation vs. Measures of Unemployment and Informal Work

\begin{tabular}{|c|c|c|c|c|c|}
\hline & $(1)$ & $(2)$ & (3) & (4) & (5) \\
\hline U3 Rate & $\begin{array}{l}0.577 \\
(1.35)\end{array}$ & & & $\begin{array}{l}0.569 \\
(1.26)\end{array}$ & \\
\hline U6 Rate & & $\begin{array}{l}0.218 \\
(0.87)\end{array}$ & & & $\begin{array}{l}-0.038 \\
(0.83)\end{array}$ \\
\hline FTE Share & & & $\begin{array}{r}-0.116^{*} \\
(0.06)\end{array}$ & $\begin{array}{l}-0.116 \\
(0.07)\end{array}$ & $\begin{array}{r}-0.117 \\
(0.07)\end{array}$ \\
\hline L. YOY ECI Change & $\begin{array}{l}0.804 \\
(0.60)\end{array}$ & $\begin{array}{l}0.880 \\
(0.56)\end{array}$ & $\begin{array}{l}0.975^{*} \\
(0.47)\end{array}$ & $\begin{array}{l}0.852 \\
(0.56)\end{array}$ & $\begin{array}{l}0.984^{*} \\
(0.53)\end{array}$ \\
\hline Constant & $\begin{array}{c}-3.992 \\
(7.27)\end{array}$ & $\begin{array}{c}-3.310 \\
(9.57)\end{array}$ & $\begin{array}{c}-0.589 \\
(1.10)\end{array}$ & $\begin{array}{l}-3.607 \\
(6.79)\end{array}$ & $\begin{array}{c}-0.168 \\
(9.14)\end{array}$ \\
\hline Time Control & Yes & Yes & Yes & Yes & Yes \\
\hline Census Division Coun & 27 & 27 & 27 & 27 & 27 \\
\hline
\end{tabular}

Note: Fixed-effect linear model. The dependent variable is the quarterly change in ECI by census division and time period, and the explanatory variables are the corresponding unemployment measures or informal-work FTE share. Share of FTE calculation is scaled up to population by census division. Model includes time controls and census division fixed effects. Standard errors in parentheses. ${ }^{*} p<0.10,{ }^{* * *} p<0.05,{ }^{* * * *} p<$ 0.01

Table A8: Quarterly Wage Inflation vs. Measures of Unemployment and Informal Work: Informal Pay Is Less than Formal Pay

\begin{tabular}{|c|c|c|c|c|c|}
\hline & (1) & (2) & (3) & (4) & (5) \\
\hline U3 Rate & $\begin{array}{l}0.577 \\
(1.35)\end{array}$ & & & $\begin{array}{l}0.421 \\
(1.17)\end{array}$ & \\
\hline U6 Rate & & $\begin{array}{l}0.218 \\
(0.87)\end{array}$ & & & $\begin{array}{l}0.009 \\
(0.76)\end{array}$ \\
\hline Share FTE, Lower & & & $\begin{array}{c}-0.197^{* *} \\
(0.08)\end{array}$ & $\begin{array}{c}-0.196^{* *} \\
(0.08)\end{array}$ & $\begin{array}{c}-0.197^{* *} \\
(0.08)\end{array}$ \\
\hline L. YOY ECI Change & $\begin{array}{l}0.804 \\
(0.60)\end{array}$ & $\begin{array}{l}0.880 \\
(0.56)\end{array}$ & $\begin{array}{l}0.923^{*} \\
(0.44)\end{array}$ & $\begin{array}{l}0.832 \\
(0.52)\end{array}$ & $\begin{array}{l}0.921^{*} \\
(0.49)\end{array}$ \\
\hline Constant & $\begin{array}{c}-3.992 \\
(7.27)\end{array}$ & $\begin{array}{l}-3.310 \\
(9.57)\end{array}$ & $\begin{array}{l}-0.553 \\
(1.02)\end{array}$ & $\begin{array}{l}-2.789 \\
(6.33)\end{array}$ & $\begin{array}{l}-0.650 \\
(8.38)\end{array}$ \\
\hline Time Control & Yes & Yes & Yes & Yes & Yes \\
\hline Census Division Count & 27 & 27 & 27 & 27 & 27 \\
\hline
\end{tabular}

Note: Fixed-effect linear model. The dependent variable is the quarterly change in ECI by census division and time period, and the explanatory variables are the corresponding unemployment measures or informal-work FTE share with lower informal pay. Share of FTE calculation is scaled up to population by census division. Model includes time controls and census division fixed effects. Standard errors in parentheses. ${ }^{*} p<$ $0.10,{ }^{* *} p<0.05,{ }^{* * *} p<0.01$

Table A9: First Difference in Wage Inflation vs. Measures of Unemployment and Informal Work

\begin{tabular}{|c|c|c|c|c|c|}
\hline & (1) & (2) & (3) & (4) & $(5)$ \\
\hline D.U3 Rate & $\begin{array}{l}2.737 \\
(1.74)\end{array}$ & & & $\begin{array}{l}2.508 \\
(1.51)\end{array}$ & \\
\hline D.U6 Rate & & $\begin{array}{l}1.825 \\
(1.14)\end{array}$ & & & $\begin{array}{l}1.156 \\
(1.09)\end{array}$ \\
\hline D.Share FTE & & & $\begin{array}{c}-0.127^{* *} \\
(0.05)\end{array}$ & $\begin{array}{c}-0.122^{* *} \\
(0.05)\end{array}$ & $\begin{array}{c}-0.109^{*} \\
(0.05)\end{array}$ \\
\hline Constant & $\begin{array}{c}3.494^{\text {*** }} \\
(0.98)\end{array}$ & $\begin{array}{c}3.920^{* * *} \\
(1.21)\end{array}$ & $\begin{array}{c}2.034^{* * *} \\
(0.41)\end{array}$ & $\begin{array}{c}3.299^{* * *} \\
(0.86)\end{array}$ & $\begin{array}{c}3.188^{* *} \\
(1.16)\end{array}$ \\
\hline Census Division Count & 18 & 18 & 18 & 18 & 18 \\
\hline
\end{tabular}

Note: OLS regression analysis. The dependent variable is the difference in raw ECI between consecutive survey waves (2015Q4-2015Q1 and 2016Q4-2015Q4), and the explanatory variables are the corresponding differences in the unemployment measures or informal-work FTE share scaled up to population. Standard errors in parentheses. ${ }^{*} p<0.10,{ }^{* *} p<0.05,{ }^{* * *} p<0.01$ 
Figure A2: Informal Work FTE Shares by Census Division and Informal Pay Condition: Scaled to U.S. Adult Population

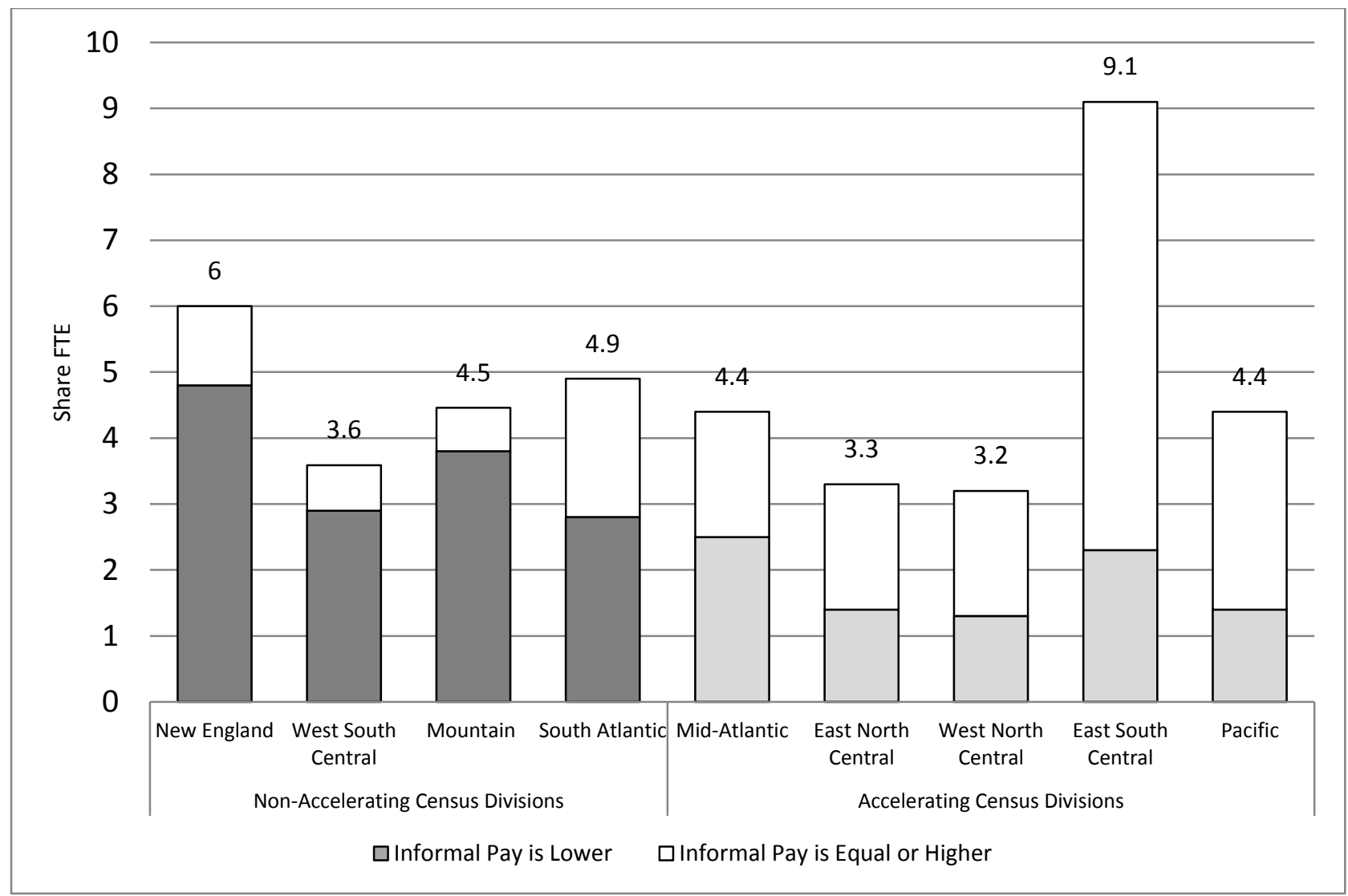




\section{Robustness Check: First Difference with Four-Quarter Differences}

Table A10: First Difference in Wage Inflation vs. Measures of Unemployment and Informal Work

\begin{tabular}{|c|c|c|c|c|c|}
\hline & (1) & (2) & (3) & (4) & $(5)$ \\
\hline \multirow[t]{2}{*}{ D.U3 Rate } & 0.446 & & & 0.381 & \\
\hline & $(0.66)$ & & & $(0.73)$ & \\
\hline \multirow[t]{2}{*}{ D.U6 Rate } & & 0.283 & & & 0.240 \\
\hline & & $(0.43)$ & & & $(0.50)$ \\
\hline \multirow[t]{2}{*}{ D.FTE Share } & & & -0.020 & -0.012 & -0.009 \\
\hline & & & $(0.04)$ & $(0.05)$ & $(0.05)$ \\
\hline \multirow[t]{2}{*}{ Constant } & $3.083^{* * *}$ & $3.133^{* * *}$ & $2.785^{* * *}$ & $3.036^{* * *}$ & $3.077^{* * *}$ \\
\hline & $(0.49)$ & $(0.56)$ & $(0.23)$ & $(0.54)$ & $(0.65)$ \\
\hline Census Division Count & 18 & 18 & 18 & 18 & 18 \\
\hline
\end{tabular}

Table A11: First Difference in Wage Inflation vs. Measures of Unemployment and Informal Work: FTE Share Scaled to Population

\begin{tabular}{|c|c|c|c|c|c|}
\hline & (1) & (2) & (3) & (4) & (5) \\
\hline \multirow[t]{2}{*}{ D.U3 Rate } & 0.446 & & & 0.391 & \\
\hline & $(0.66)$ & & & $(0.74)$ & \\
\hline \multirow[t]{2}{*}{ D.U6 Rate } & & 0.283 & & & 0.252 \\
\hline & & $(0.43)$ & & & $(0.51)$ \\
\hline \multirow[t]{2}{*}{ D.FTE Share } & & & -0.013 & -0.006 & -0.004 \\
\hline & & & $(0.03)$ & $(0.03)$ & $(0.03)$ \\
\hline \multirow[t]{2}{*}{ Constant } & $3.083^{* * *}$ & $3.133^{* * * *}$ & $2.786^{* * *}$ & $3.043^{* * *}$ & $3.093^{* * *}$ \\
\hline & $(0.49)$ & $(0.56)$ & $(0.23)$ & $(0.54)$ & $(0.66)$ \\
\hline Census Division Count & 18 & 18 & 18 & 18 & 18 \\
\hline
\end{tabular}

Note: OLS regression analysis. The dependent variable is the raw difference in ECI between (2015Q4-2014Q4 and 2016Q42015Q4), and the explanatory variables are the corresponding differences in the unemployment measures or the difference in informal-work FTE share scaled up to population between survey waves. Standard errors in parentheses. ${ }^{*} p<0.10,{ }^{* *} p<0.05,{ }^{* * *}$ $p<0.01$ 